\title{
The Long-Run Impacts of Specialized Programming for High-Achieving Students \\ Online Appendix
}

Sarah Cohodes

Teachers College Columbia University and NBER

cohodes@tc.columbia.edu 


\section{Contents}

A Additional Robustness Checks $\quad 1$

B Additional Figures and Tables $\quad 9$

$\begin{array}{ll}\text { C Results for Additional Subgroups } & 26\end{array}$

D Results based on 6th Grade Eligibility $\quad 31$ 


\section{A Additional Robustness Checks}

Online Appendix A discusses additional robustness checks and provides more detail on some of the robustness checks described in Section V.

\section{A Additional Bandwidths}

In Panel B of Online Appendix Tables A.1 and A.2, I report estimates where I vary the bandwidths but otherwise continue to use local linear regression with a triangular kernel. Generally, with smaller bandwidths, magnitudes are larger and less precise due to the small sample size. With the smallest bandwidth of 0.25 , in the Black and Latino student sample, no impacts are statistically significant; for all students the AP estimate is marginally significant. Given that the bandwidths employed in the main results are very close to 0.5 , estimates from this specification closely conform to the baseline specification, and are useful to compare across samples using the exact same bandwidth. Treatment effects are slightly smaller with the 0.75 and 1 unit bandwidths, with standard errors predictably smaller, with the overall conclusions similar to the main findings.

Estimates using the CCT bandwidths generated for each outcome are similar, though there is small variation in both directions in terms of magnitudes. The college enrollment estimate for all students becomes statistically significant, and the high school graduation estimate for Black and Latino students is no longer significant. The Imbens and Kalyanaraman (2012) procedure typically generates larger bandwidths than the CCT bandwidths, ranging between 0.61 and 1.15 for all students and 0.47 to 0.94 for Black and Latino students. For Black and Latino students, estimates using IK bandwidths line up closely with the baseline specification, with smaller standard errors, and the college quality estimate becomes marginally statistically significant. For all students, results are quite similar though a little smaller, which is not surprising given that the IK bandwidths for this sample tend to be on the larger side.

\section{A Split Sample Test}

In addition to the placebo test in Section V.B, a second piece of evidence takes a different approach to the cutoffs. To address the concern that identifying the cutoff on the same sample that I am estimating the outcomes introduces endogeneity, I introduce a split sample approach as a robustness check in Online Appendix Table A.3. Here, I split each cohort into two randomly selected samples the threshold estimation sample and the outcome estimation sample - 10,000 times. On the former sample I estimate the empirical cutoffs using the exact same methods described in Section III.B. ${ }^{1}$ I then apply that threshold to the latter sample, and estimate the fuzzy regression discontinuity estimates using my standard specification. The median estimate for each outcome from the 10,000 runs serves as the impact estimate of interest, and estimates at the 2.5th and 97.5th percentiles form a nonparametric 95 percent confidence interval, and estimates at the 5 th and 95 th percentiles serve as a 90 percent confidence interval. As shown in Online Appendix Table A.3, these nonparametric confidence intervals always include zero. However, the medians are generally in line with the main results, though slightly smaller, and the high school graduation and four-year college enrollment outcomes for Black and Latino students become nonzero around the 20th percentile. Given that this procedure halves the sample size used to estimate the effects, it is not surprising that there are a large number of outliers, and it is reassuring that the median of the estimates are generally

\footnotetext{
${ }^{1}$ The correlation between these thresholds and the empirically derived thresholds for the full sample is 0.96 .
} 
similar. On the other hand, had I used the split sample approach as my main estimation strategy, I would not have found precise support for positive impacts of the program.

\section{A Attrition}

As discussed in Section III, there is no differential attrition by program eligibility, as shown in Online Appendix Table B.3. However, from middle school forward, there is a somewhat high level of overall attrition, with around 15 to 30 percent of the students not appearing in the data in later grades, with high school grades having the largest level of missing data. These students either leave the state, attend private schools, or drop out of high school. The state sends most students (84 percent) in my sample to match to the NSC, my source for college information, as seen in Column $(10) .^{2}$

To address the concern that the somewhat high level of attrition might bias my findings, I rerun my analyses to account for attrition by substituting predicted outcomes for those missing data. To generate predicted outcomes, I use students beneath the AWC eligibility threshold to predict performance on outcome variables, using the demographic characteristics and baseline test scores listed in Panel A of Table 1, along with a year by school fixed effect. Applying these predicted probabilities to those missing data provides allows me to test whether attrition is driving my results. The findings are displayed in the last line of Panel A of Online Appendix Tables A.1 and A.2. Estimates using this strategy are quite similar, though slightly smaller than those in the baseline specification. This is not surprising, given that there is no discontinuity in the predicted probabilities applied to all students, as shown in Online Appendix Figures B.3 to B.5. In addition to this evidence using predicted outcomes, college enrollment results are some of the most consistent throughout the robustness checks, and those outcomes have lower levels of attrition. Results using only the first two cohorts of data (not shown) - in which 95 percent of students are sent to the NSC for matching - are very similar, though less precise given the smaller sample size.

\section{References}

Calonico, Sebastian, Matias D Cattaneo, Max H Farrell, and Rocio Titiunik. 2017. "rdrobust: Software for regression discontinuity designs." Stata Journal, 17(2): 372-404.

Imbens, Guido, and Karthik Kalyanaraman. 2012. "Optimal bandwidth choice for the regression discontinuity estimator." The Review of Economic Studies, 79(3): 933-959.

\footnotetext{
${ }^{2}$ This is because DESE sent some nongraduates to the NSC who enroll in at least 8th grade in a Massachusetts high schools and has occasionally conducted additional matches for researchers.
} 
Figure A.1: Estimates of the Effect of AWC Eligibility on MCAS Outcomes at Placebo Cutoffs

\section{A. Elementary School Scores}
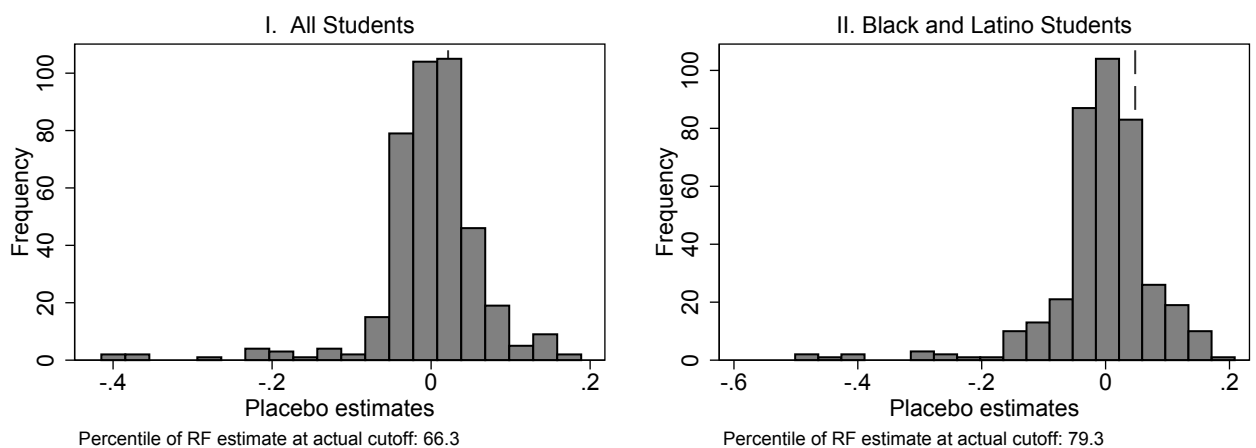

\section{B. Middle School Scores}
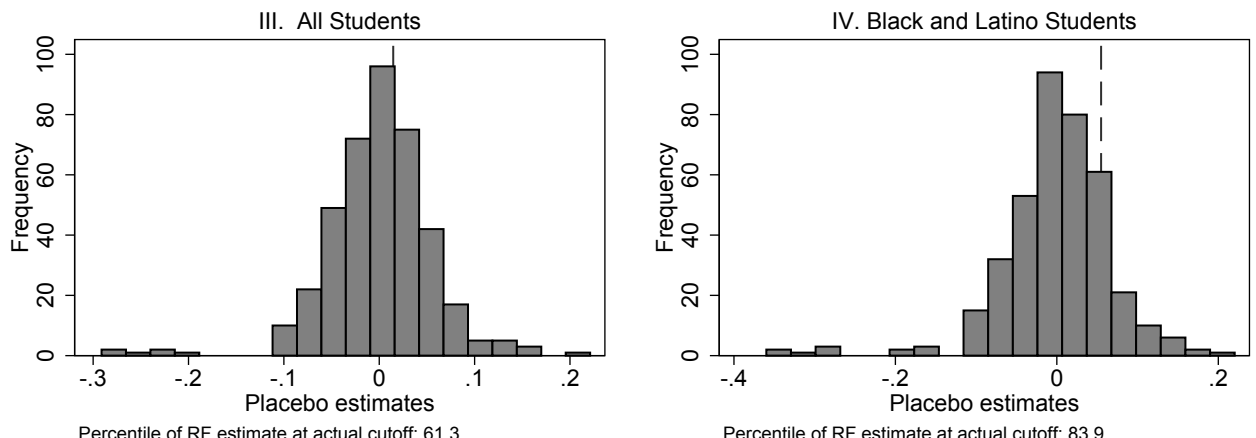

Notes: The above figure shows the frequency of estimates of the effect of AWC eligibility (the reduced form) on MCAS outcomes at placebo thresholds for all students (left side) and Black and Latino students (right side). Placebo thresholds place the threshold every 0.01 from $[-3.2,1]$, which is the area over which there are a sufficient number of observations on either side of the threshold to generate a regression discontinuity estimate. At each false cutoff, the standard specification is employed to estimate the effect of the offer of AWC on various outcomes. The dashed vertical lines are at the estimate of the reduced form (RF) at the standard cutoff. The percentile of the standard estimate is displayed under each panel. The figure displays estimates where at least 50 students are above the cutoff and 50 students are below the cutoff. 


\section{A. Took Any AP Exam}
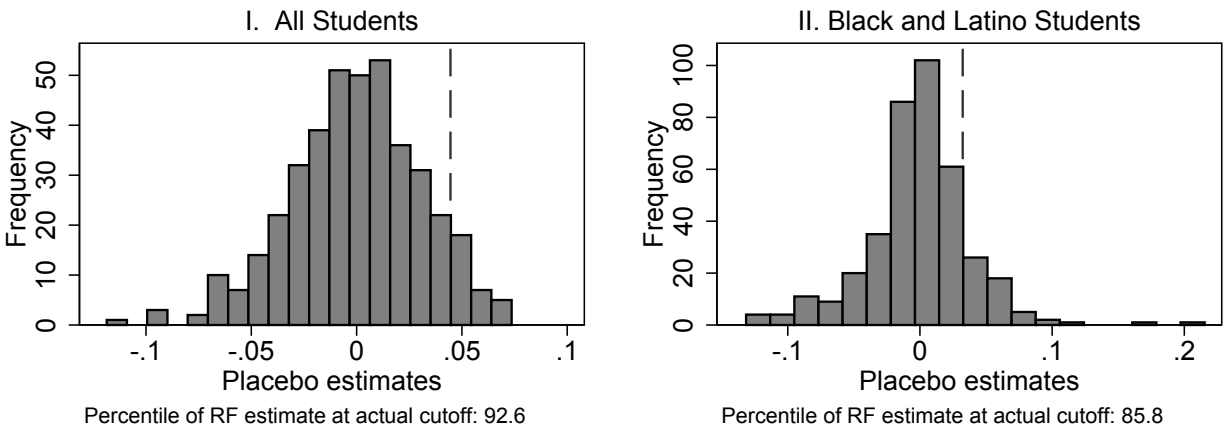

Percentile of RF estimate at actual cutoff: 85.8

\section{B. SAT Score (2400)}
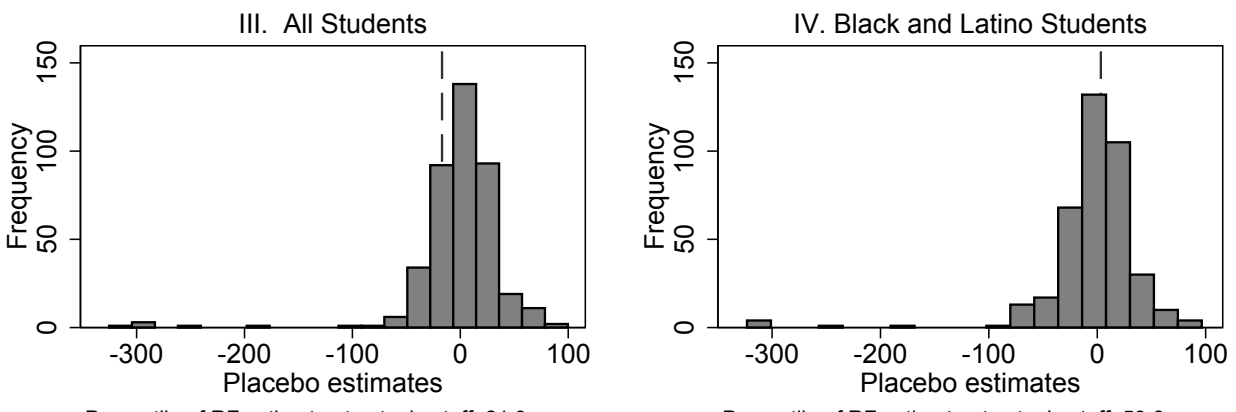

Percentile of RF estimate at actual cutoff: 21.3

Percentile of RF estimate at actual cutoff: 53.6

\section{Graduated High School On Time}
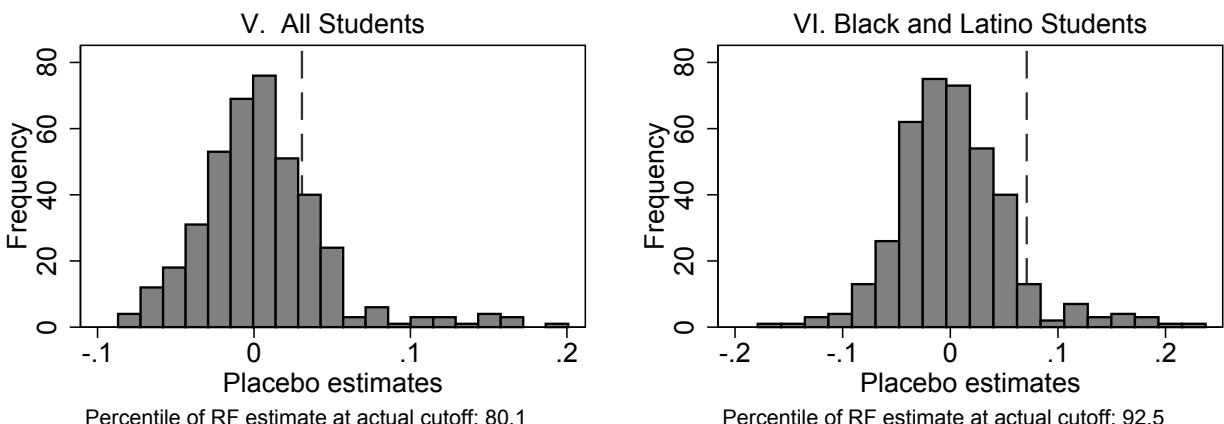

Percentile of RF estimate at actual cutoff: 92.5

Notes: The above figure shows the frequency of estimates of the effect of AWC eligibility (the reduced form) on high school outcomes at placebo thresholds for all students (left side) and Black and Latino students (right side). Placebo thresholds place the threshold every 0.01 from $[-3.2,1]$, which is the area over which there are a sufficient number of observations on either side of the threshold to generate a regression discontinuity estimate. At each false cutoff, the standard specification is employed to estimate the effect of the offer of AWC on various outcomes. The dashed vertical lines are at the estimate of the reduced form (RF) at the standard cutoff. The percentile of the standard estimate is displayed under each panel. The figure displays estimates where at least 50 students are above the cutoff and 50 students are below the cutoff. 
Figure A.3: Estimates of the Effect of AWC Eligibility on College Outcomes at Placebo Cutoffs

\section{A. Enrolled Any College On Time}
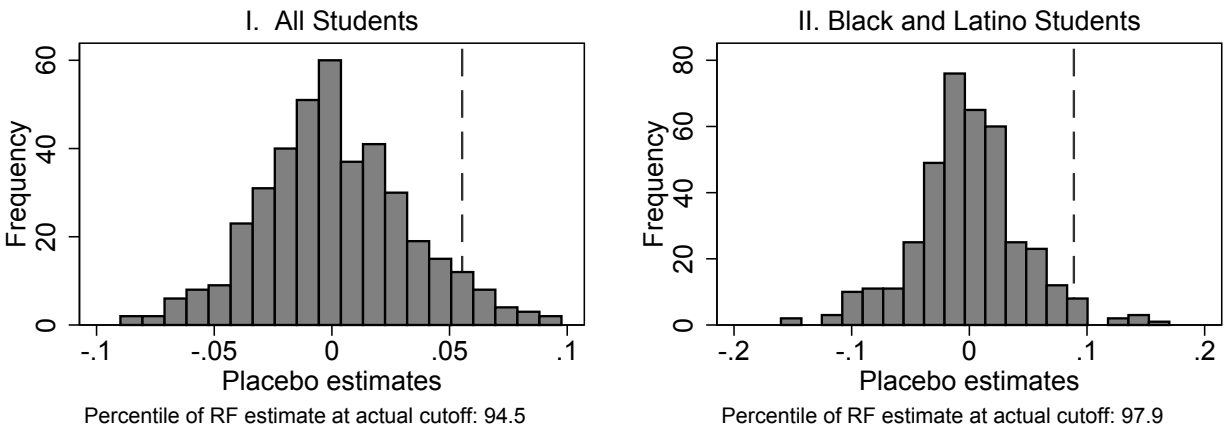

Percentile of RF estimate at actual cutoff: 97.9

\section{B. Enrolled 4 Year College On Time}
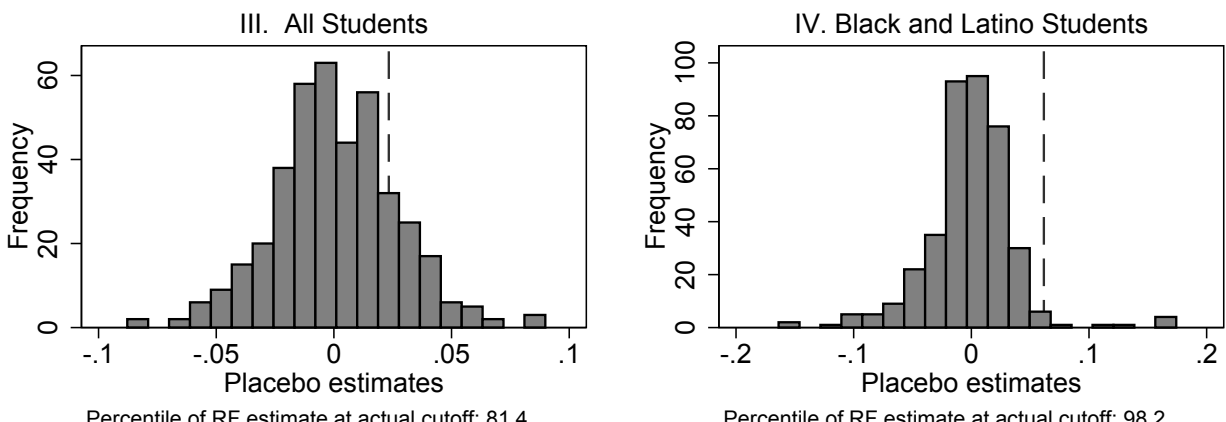

\section{College Quality}
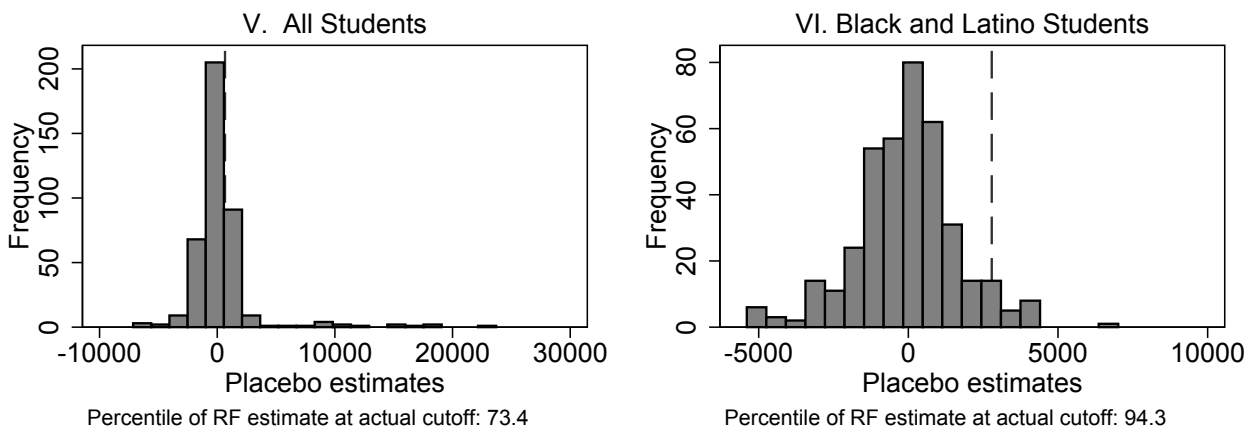

Percentile of RF estimate at actual cutoff: 94.3

Notes: The above figure shows the frequency of estimates of the effect of AWC eligibility (the reduced form) on college outcomes at placebo thresholds for all students (left side) and Black and Latino students (right side). Placebo thresholds place the threshold every 0.01 from $[-3.2,1]$, which is the area over which there are a sufficient number of observations on either side of the threshold to generate a regression discontinuity estimate. At each false cutoff, the standard specification is employed to estimate the effect of the offer of AWC on various outcomes. The dashed vertical lines are at the estimate of the reduced form $(\mathrm{RF})$ at the standard cutoff. The percentile of the standard estimate is displayed under each panel. The figure displays estimates where at least 50 students are above the cutoff and 50 students are below the cutoff. 


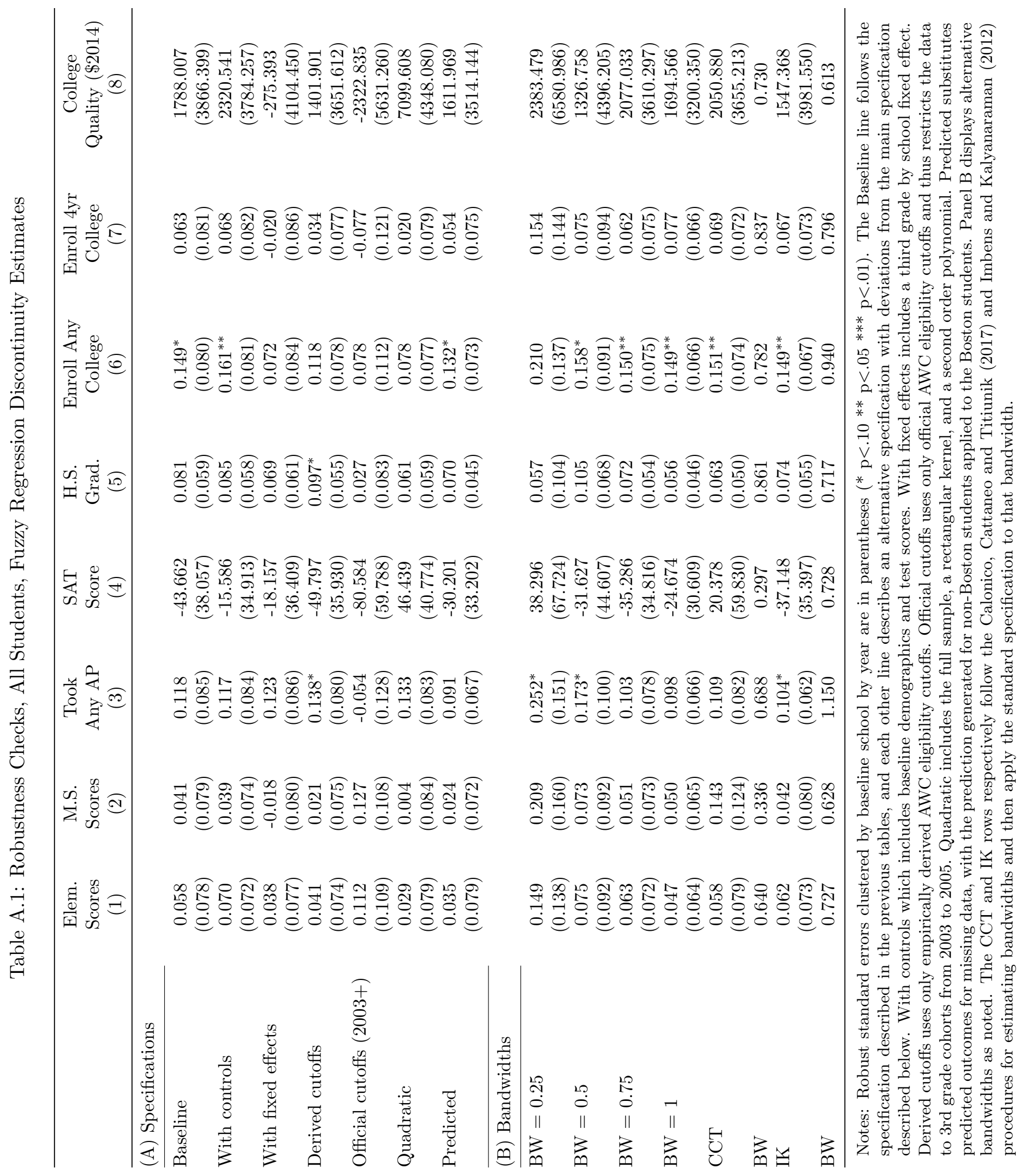




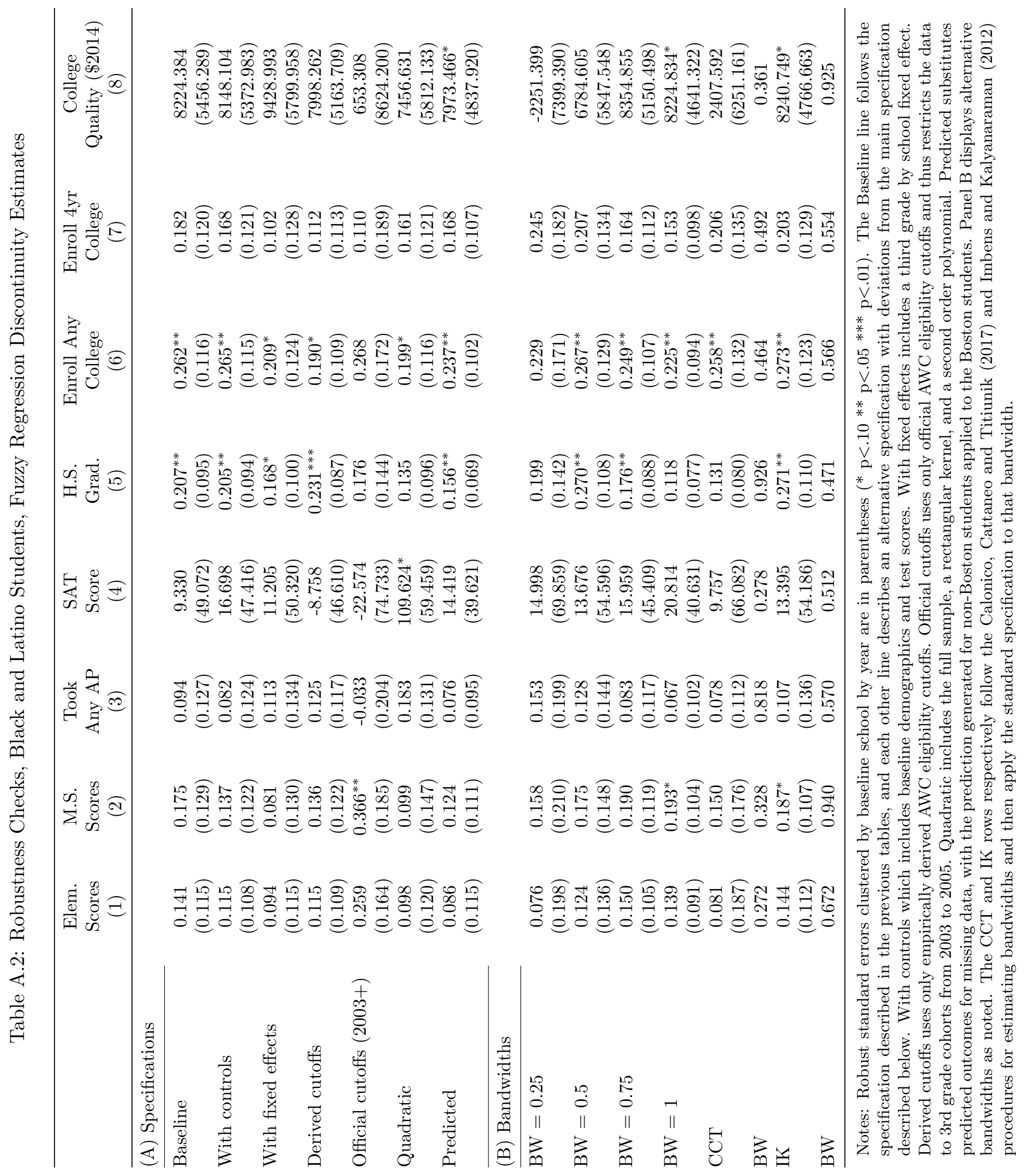




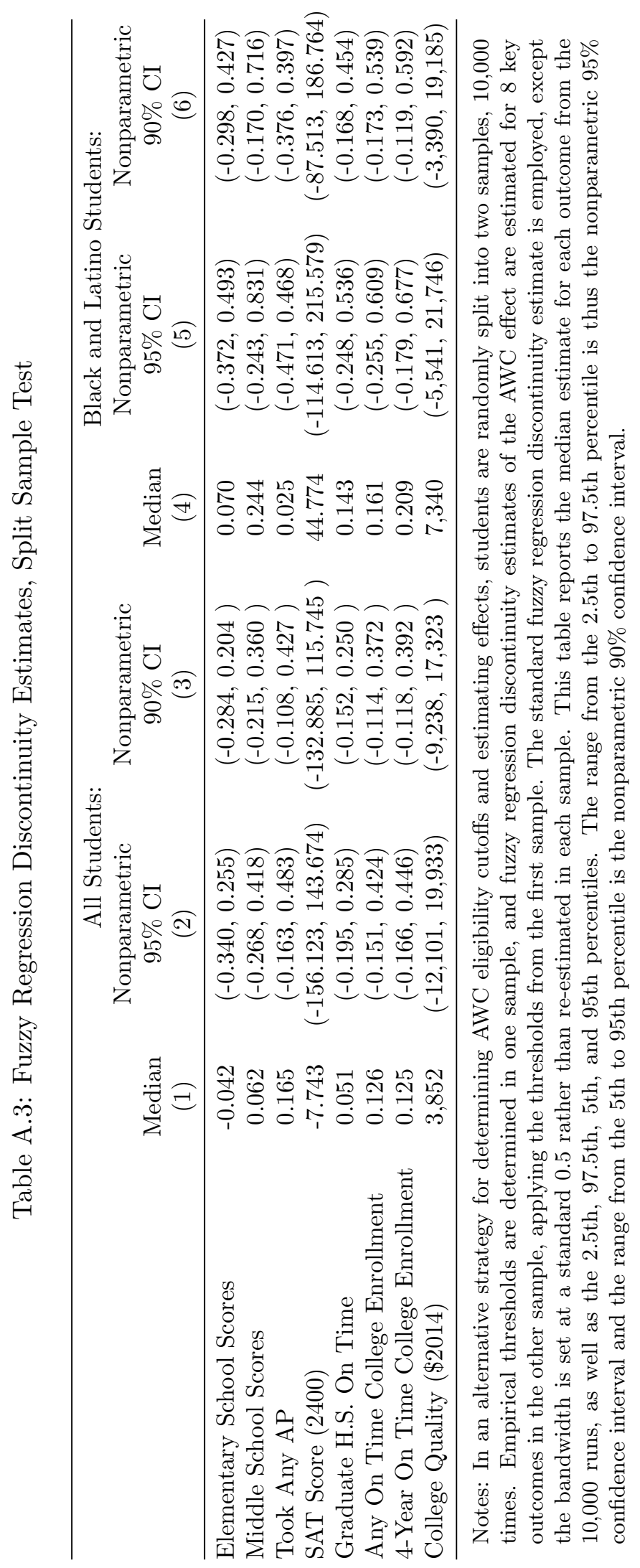




\section{B Additional Figures and Tables}

Figure B.1: Distribution of Scores near the Threshold
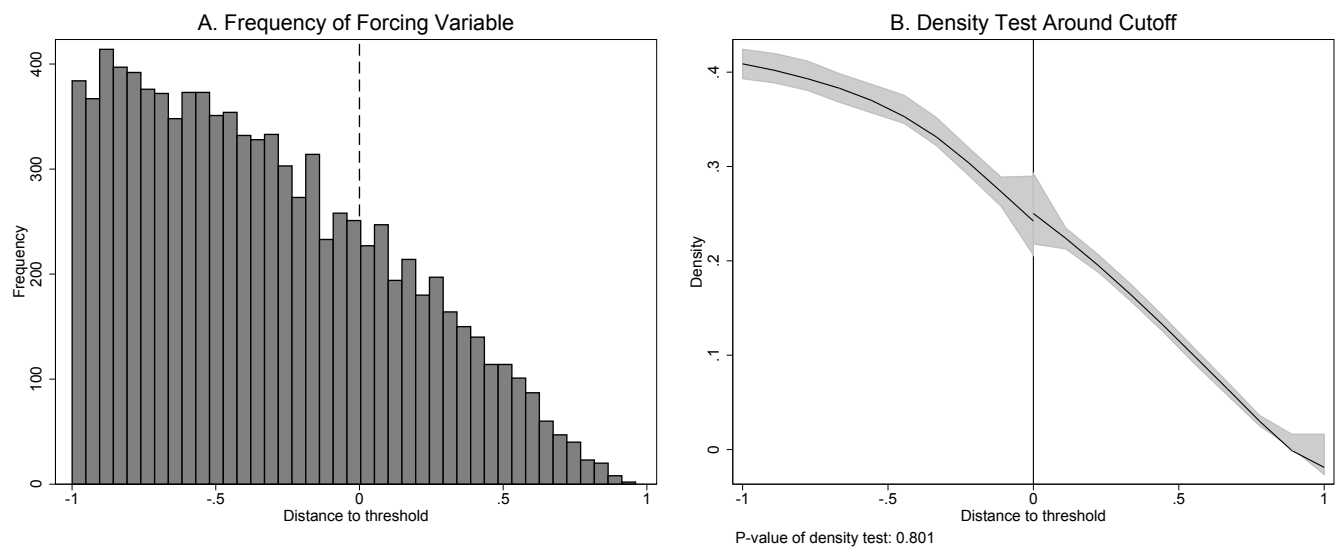

Notes: This figure shows the distribution of the running variable for the third grade cohorts from 2001 to 2005 within the bandwidth of 1 around the eligibility threshold. The running variable is the distance of a student's combined math and reading Stanford 9 scores from a given year's AWC threshold. Panel A shows the frequency of scores, and Panel B shows a density test at the threshold from Catteneo et al. (2017). 
Figure B.2: Covariate Balance
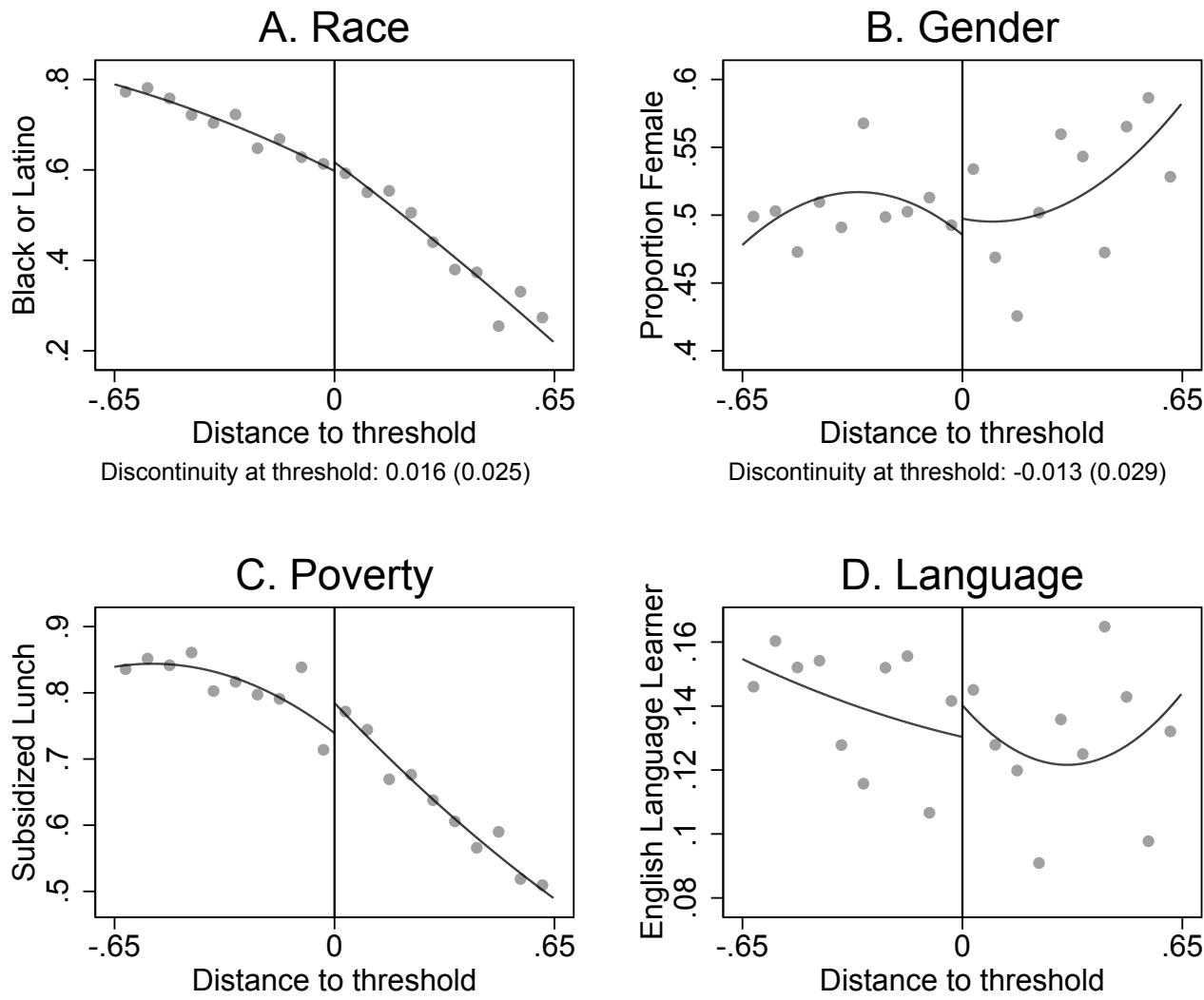

Discontinuity at threshold: $0.025(0.025)$

Discontinuity at threshold: $0.007(0.016)$
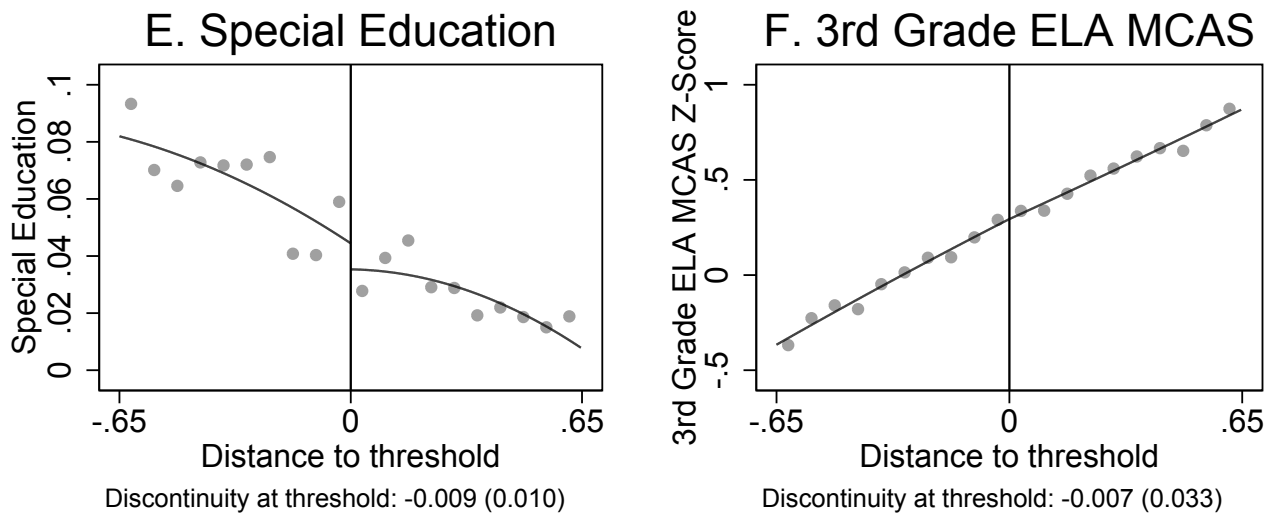

Notes: The above figure shows descriptive characteristics of students by the running variable for the 3rd grade cohorts from 2001 to 2005 within the bandwidth of 0.65. A quadratic fit is imposed on either side of the threshold. Each dot represents the average of the descriptive characteristics for a bin of width 0.065 . 
Figure B.3: Predicted MCAS Outcomes by Distance to Eligbility Threshold

\section{A. Elementary School Scores}
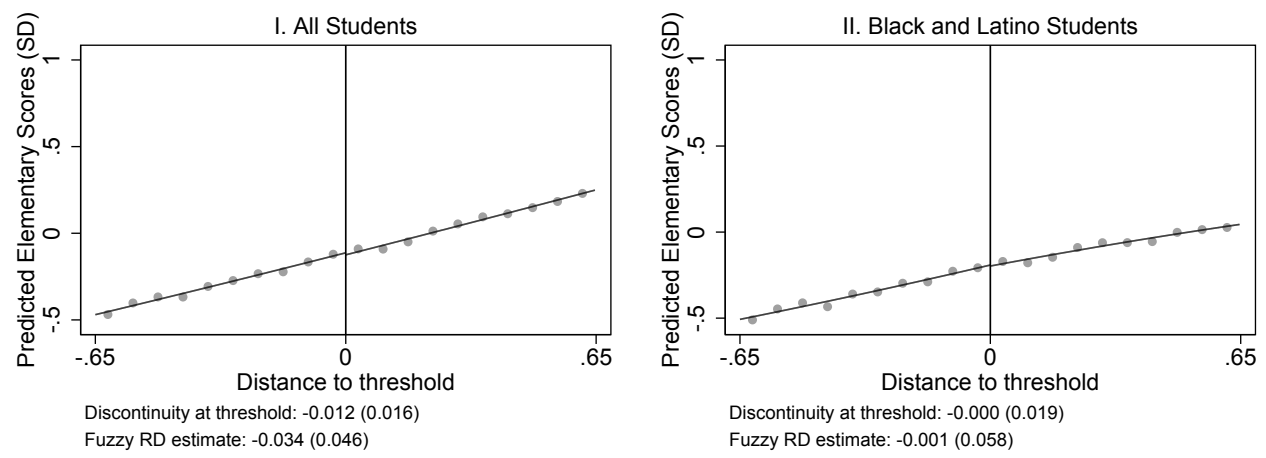

B. Middle School Scores
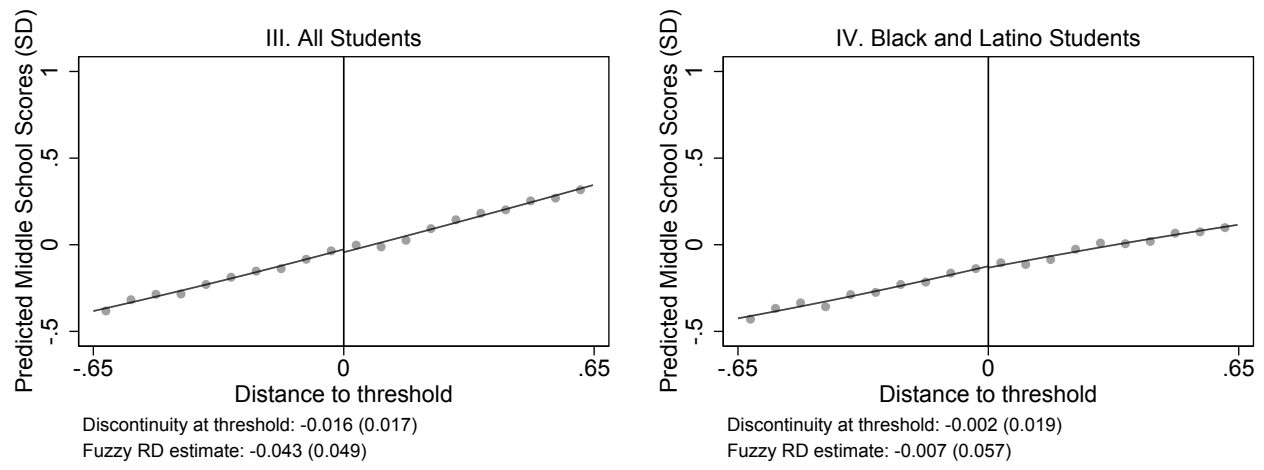

Notes: The above figure shows average predicted MCAS outcomes for bins of width 0.065 on either side of the threshold for all students (left side) and Black and Latino students (right side) within the bandwidth of 0.65 around the eligibility threshold. A quadratic fit is imposed on either side of the threshold. Predicted outcomes are generated by predicting the relationship between baseline characteristics and outcomes for students below the threshold of AWC eligibility and assigning those fitted values to students missing outcome data. 
Figure B.4: Predicted High School Outcomes by Distance to Eligbility Threshold

\section{A. Took Any AP Exam}
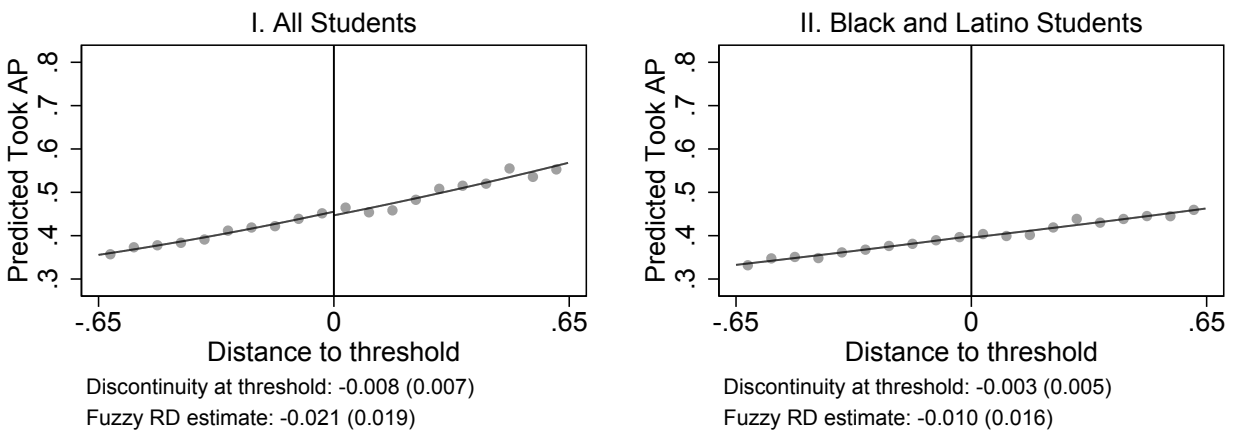

B. SAT Score $(2400)$
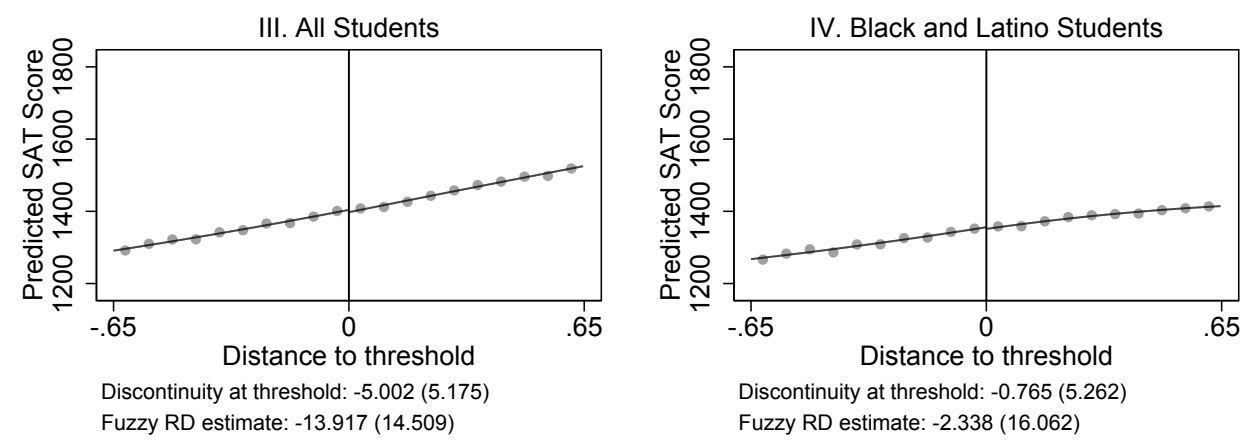

\section{Graduated High School On Time}
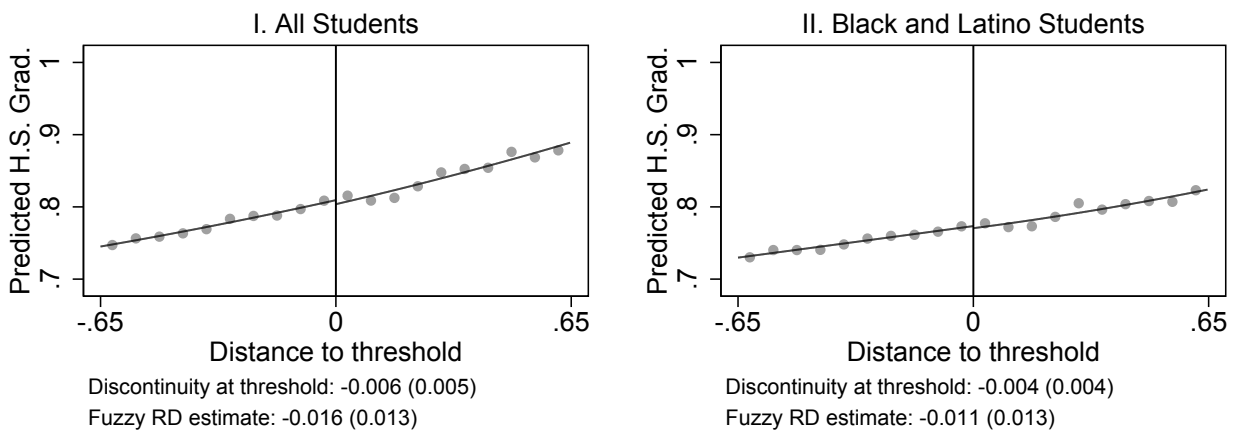

Notes: The above figure shows average predicted high school outcomes for bins of width 0.065 on either side of the threshold for all students (left side) and Black and Latino students (right side) within the bandwidth of 0.65 around the eligibility threshold. A quadratic fit is imposed on either side of the threshold. Predicted outcomes are generated by predicting the relationship between baseline characteristics and outcomes for students below the threshold of AWC eligibility and assigning those fitted values to students missing outcome data. 
Figure B.5: Predicted College Outcomes by Distance to Eligbility Threshold

\section{A. Enrolled Any College On Time}
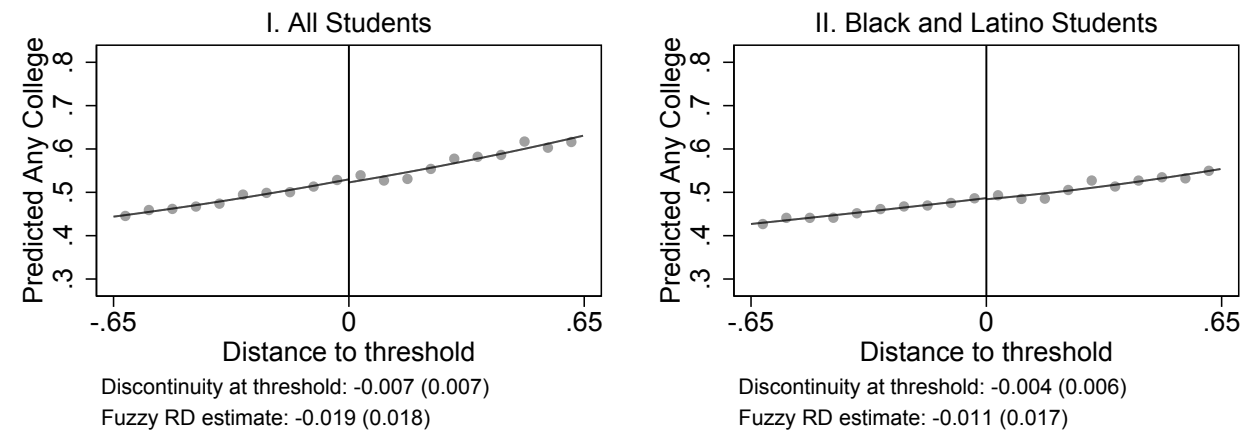

\section{B. Enrolled 4 Year College On Time}
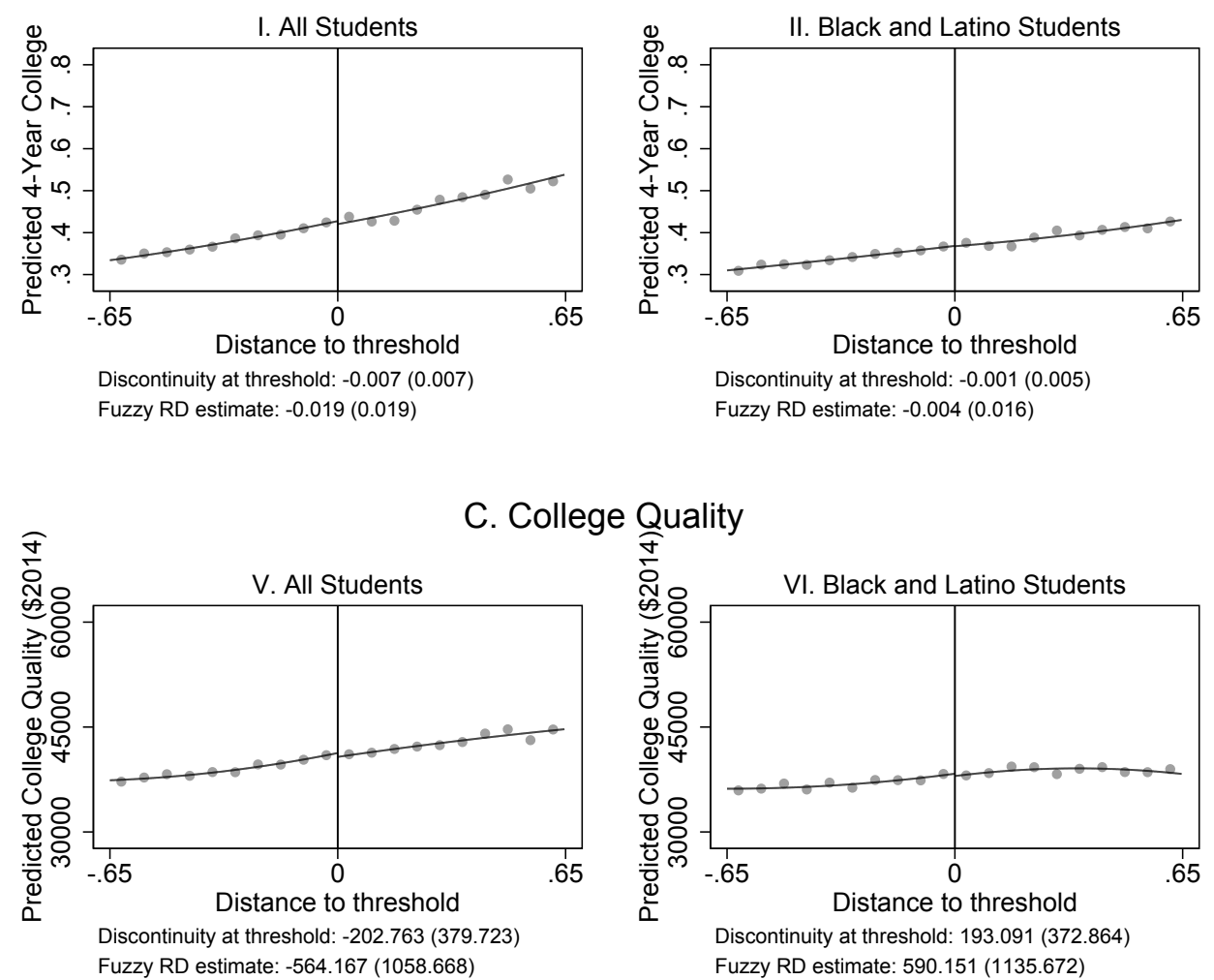

Notes: The above figure shows average predicted college outcomes for bins of width 0.065 on either side of the threshold for all students (left side) and Black and Latino students (right side) within the bandwidth of 0.65 around the eligibility threshold. A quadratic fit is imposed on either side of the threshold. Predicted outcomes are generated by predicting the relationship between baseline characteristics and outcomes for students below the threshold of AWC eligibility and assigning those fitted values to students missing outcome data. 
Table B.1: Characteristics of Students who Take-Up AWC, by AWC Eligibility

\begin{tabular}{lcc}
\hline & Below & Above \\
& Threshold & Threshold \\
& $(1)$ & $(2)$ \\
\hline Black & -0.010 & 0.021 \\
& $(0.013)$ & $(0.031)$ \\
Latino & -0.001 & 0.001 \\
& $(0.014)$ & $(0.037)$ \\
Asian & -0.029 & $0.082^{* * *}$ \\
& $(0.018)$ & $(0.030)$ \\
Other race & $0.089^{*}$ & 0.028 \\
& $(0.047)$ & $(0.110)$ \\
Subsidized lunch & $0.047^{* * *}$ & $0.045^{*}$ \\
& $(0.012)$ & $(0.023)$ \\
English language learner & -0.005 & -0.028 \\
& $(0.010)$ & $(0.034)$ \\
Special education & $-0.178^{* * *}$ & $-0.310^{* * *}$ \\
& $(0.011)$ & $(0.060)$ \\
3rd grade ELA MCAS & $0.029^{* * *}$ & $0.098^{* * *}$ \\
& $(0.004)$ & $(0.020)$ \\
3rd grade school has AWC & -0.007 & -0.008 \\
& $(0.011)$ & $(0.024)$ \\
Constant & $0.513^{* * *}$ & $0.415^{* * *}$ \\
& $(0.015)$ & $(0.032)$ \\
R-squared & & 0.030 \\
N & 0.033 & 2,309 \\
\hline
\end{tabular}

Notes: Robust standard errors clustered by baseline school by year are in parentheses $(* \mathrm{p}<.10 * * \mathrm{p}<.05 * * *$ $\mathrm{p}<.01)$. This table shows the characteristics of students who enroll in AWC, both if the qualify given their test score and if they do not. The outcome is enrollment in AWC in 4th grade and the regression controls for year fixed effects. All student characteristics are measured in the 3rd grade. The excluded group are male, white students who do not participate in the subsidized lunch, special education or English language learner programs. The sample is restricted to 3rd graders enrolled in Boston Public Schools in the fall of 2001 to 2005 . Columns (1) restricts this sample further to those below eligibility threshold for AWC. Column (2) restricts this sample further to those above eligibility threshold for AWC. 


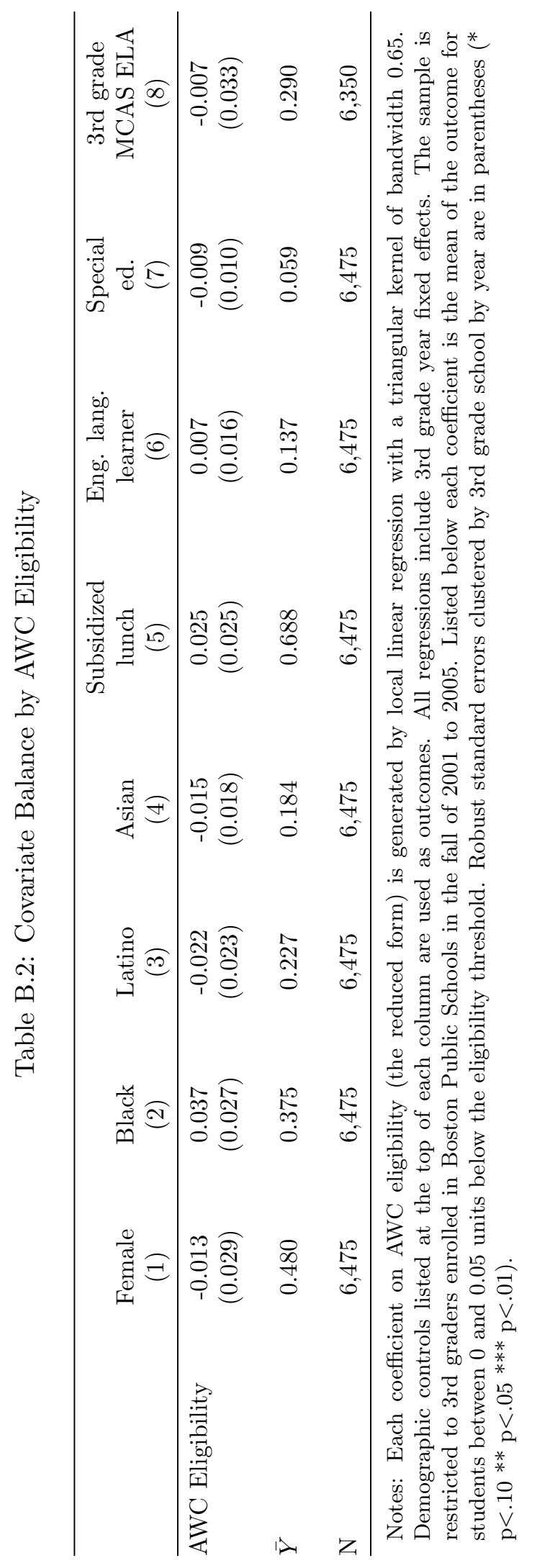




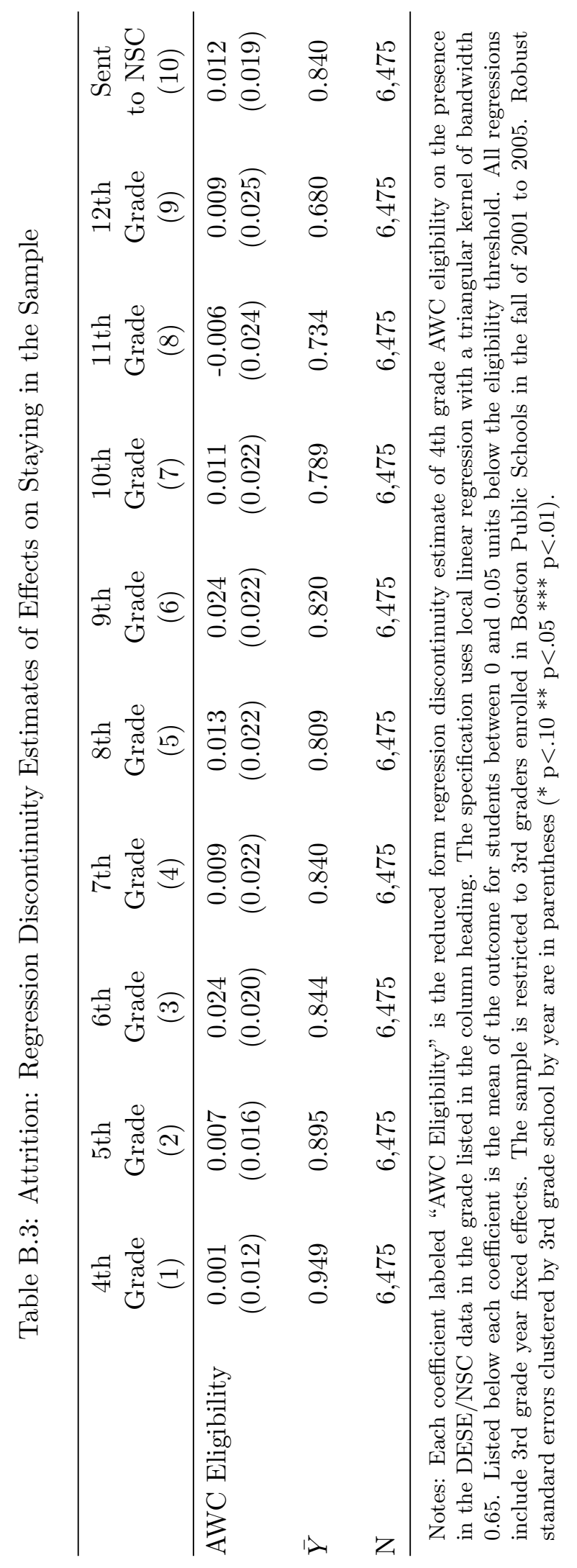




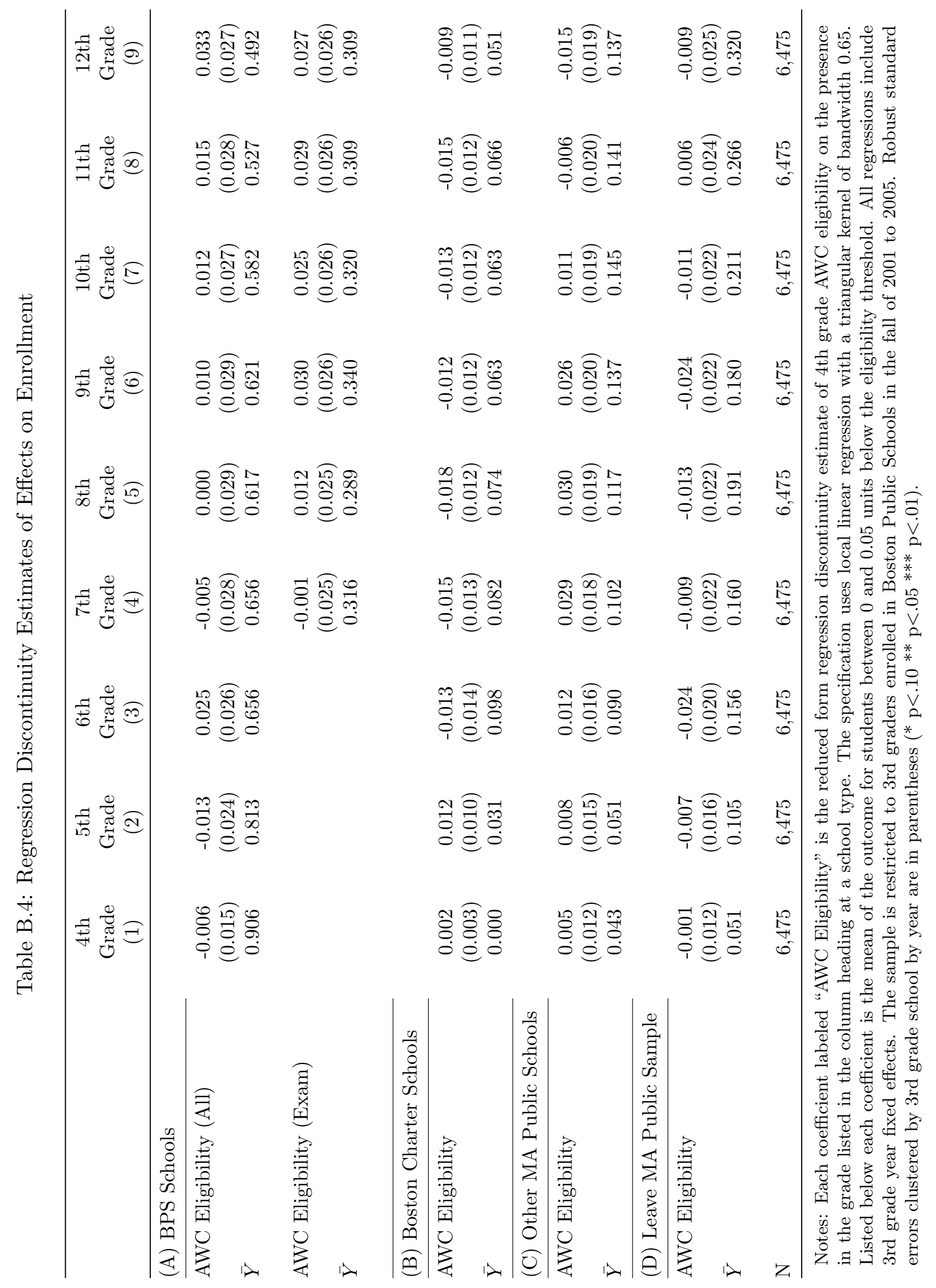




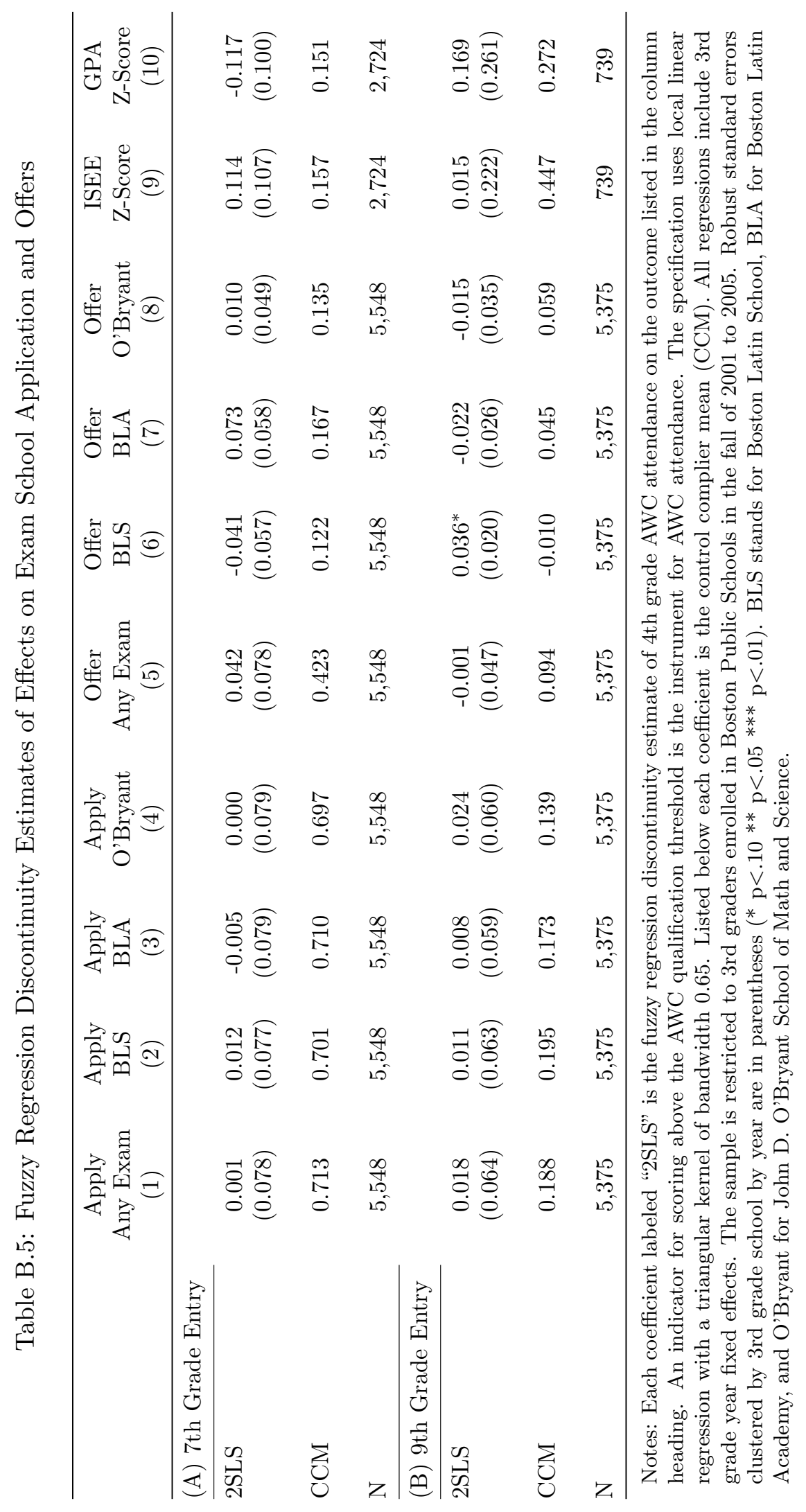


Table B.6: Fuzzy Regression Discontinuity Estimates of Effects on Subject Specific MCAS Scores

\begin{tabular}{|c|c|c|c|c|c|c|}
\hline & $\begin{array}{c}\text { ELA } \\
(1)\end{array}$ & $\begin{array}{c}\text { Math } \\
(2)\end{array}$ & $\begin{array}{c}\text { Science } \\
(3)\end{array}$ & $\begin{array}{c}\text { Writing } \\
\text { Composition } \\
(4)\end{array}$ & $\begin{array}{l}\text { Writing Topic } \\
\text { Development } \\
\quad(5)\end{array}$ & $\begin{array}{c}\text { Top Score } \\
\text { Any Subject } \\
(6)\end{array}$ \\
\hline \multicolumn{7}{|c|}{ (A) Elementary School } \\
\hline 2SLS & $\begin{array}{c}0.105 \\
(0.096)\end{array}$ & $\begin{array}{c}0.044 \\
(0.090)\end{array}$ & $\begin{array}{c}0.077 \\
(0.104)\end{array}$ & $\begin{array}{c}0.122 \\
(0.126)\end{array}$ & $\begin{array}{c}-0.025 \\
(0.122)\end{array}$ & $\begin{array}{c}0.032 \\
(0.042)\end{array}$ \\
\hline CCM & 0.321 & 0.239 & -0.034 & 0.153 & 0.323 & 0.290 \\
\hline $\mathrm{N}$ (students) & 6,123 & 6,112 & 5,843 & 6,077 & 6,077 & 6,161 \\
\hline \multicolumn{7}{|c|}{ (B) Middle School } \\
\hline 2SLS & $\begin{array}{c}0.020 \\
(0.096)\end{array}$ & $\begin{array}{c}0.016 \\
(0.082)\end{array}$ & $\begin{array}{c}0.043 \\
(0.122)\end{array}$ & $\begin{array}{c}-0.024 \\
(0.128)\end{array}$ & $\begin{array}{c}0.103 \\
(0.130)\end{array}$ & $\begin{array}{c}-0.007 \\
(0.031)\end{array}$ \\
\hline $\mathrm{CCM}$ & 0.493 & 0.308 & -0.080 & 0.270 & 0.294 & 0.231 \\
\hline N (students) & 5,737 & 5,684 & 5,352 & 5,419 & 5,419 & 5,741 \\
\hline \multicolumn{7}{|c|}{ (C) 10th Grade } \\
\hline $2 \mathrm{SLS}$ & $\begin{array}{l}0.223^{*} \\
(0.115)\end{array}$ & $\begin{array}{l}0.237^{* *} \\
(0.104)\end{array}$ & $\begin{array}{c}0.023 \\
(0.124)\end{array}$ & $\begin{array}{c}0.157 \\
(0.142)\end{array}$ & $\begin{array}{c}0.053 \\
(0.125)\end{array}$ & $\begin{array}{c}0.011 \\
(0.069)\end{array}$ \\
\hline $\mathrm{CCM}$ & 0.407 & 0.084 & 0.236 & 0.087 & 0.263 & 0.797 \\
\hline N (students) & 4,904 & 4,914 & 5,087 & 4,914 & 4,914 & 5,202 \\
\hline
\end{tabular}

Notes: Each coefficient labeled "2SLS" is the fuzzy regression discontinuity estimate of 4 th grade AWC attendance on the outcome listed in the column heading. An indicator for scoring above the AWC qualification threshold is the instrument for AWC attendance. The specification uses local linear regression with a triangular kernel of bandwidth 0.65. Listed below each coefficient is the control complier mean (CCM). All regressions include 3rd grade year fixed effects. The sample is restricted to 3rd graders enrolled in Boston Public Schools in the fall of 2001 to 2005. Elementary school regressions stack 4th and 5th grade outcomes, include grade fixed effects, and double cluster standard errors by 3rd grade school by year and student. Middle school regressions stack 6th, 7th, and 8th grade outcomes, include grade fixed effects, and double cluster standard errors by 3rd grade school by year and student $(* \mathrm{p}<.10 * * \mathrm{p}<.05 * * * \mathrm{p}<.01)$. 
Table B.7: Fuzzy Regression Discontinuity Estimates of Effects on Class Rank and MCAS Thresholds

\begin{tabular}{|c|c|c|c|c|c|}
\hline & & ss Rank: & & MCAS T & holds: \\
\hline & $\begin{array}{c}\text { Elementary } \\
\text { School } \\
(1)\end{array}$ & $\begin{array}{c}\text { Middle } \\
\text { School } \\
\quad(2)\end{array}$ & $\begin{array}{c}\text { 10th } \\
\text { Grade } \\
(3)\end{array}$ & $\begin{array}{c}\text { Passed } \\
\text { Grad. Req. } \\
\text { (4) }\end{array}$ & $\begin{array}{c}\text { Adams } \\
\text { Eligible } \\
\quad(5)\end{array}$ \\
\hline (A) All Stude & & & & & \\
\hline 2SLS & $\begin{array}{c}-5.775^{* *} \\
(2.877)\end{array}$ & $\begin{array}{c}1.947 \\
(3.151)\end{array}$ & $\begin{array}{c}4.501 \\
(5.087)\end{array}$ & $\begin{array}{l}0.110^{* *} \\
(0.052)\end{array}$ & $\begin{array}{c}0.128 \\
(0.081)\end{array}$ \\
\hline $\mathrm{CCM}$ & 71.704 & 65.678 & 53.884 & 0.848 & 0.536 \\
\hline $\mathrm{N}$ (students) & 6,159 & 5,741 & 4,878 & 5,098 & 5,098 \\
\hline (B) Black an & & & & & \\
\hline 2SLS & $\begin{array}{l}-5.060 \\
(4.082)\end{array}$ & $\begin{array}{c}4.976 \\
(4.689)\end{array}$ & $\begin{array}{c}5.566 \\
(7.521)\end{array}$ & $\begin{array}{l}0.160^{*} \\
(0.088)\end{array}$ & $\begin{array}{c}0.151 \\
(0.124)\end{array}$ \\
\hline $\mathrm{CCM}$ & 74.571 & 67.095 & 59.971 & 0.798 & 0.432 \\
\hline $\mathrm{N}$ (students) & 3,836 & 3,523 & 2,950 & 3,110 & 3,110 \\
\hline (C) Asian anc & & & & & \\
\hline 2SLS & $\begin{array}{l}-5.779 \\
(4.520)\end{array}$ & $\begin{array}{l}-1.219 \\
(4.205)\end{array}$ & $\begin{array}{c}4.157 \\
(6.548)\end{array}$ & $\begin{array}{c}0.074 \\
(0.062)\end{array}$ & $\begin{array}{c}0.119 \\
(0.101)\end{array}$ \\
\hline $\mathrm{CCM}$ & 67.869 & 63.930 & 47.219 & 0.889 & 0.642 \\
\hline N (students) & 2,323 & 2,218 & 1,928 & 1,988 & 1,988 \\
\hline
\end{tabular}

Notes: Each coefficient labeled "2SLS" is the fuzzy regression discontinuity estimate of 4th grade AWC attendance on the outcome listed in the column heading. An indicator for scoring above the AWC qualification threshold is the instrument for AWC attendance. The specification uses local linear regression with a triangular kernel of bandwidth 0.65. Listed below each coefficient is the control complier mean (CCM). All regressions include 3rd grade year fixed effects The sample is restricted to 3rd graders enrolled in Boston Public Schools in the fall of 2001 to 2005. Elementary school regressions stack 4th and 5th grade outcomes, include grade fixed effects, and double cluster standard errors by 3rd grade school by year and student. Middle school regressions stack 6th, 7th, and 8th grade outcomes, include grade fixed effects, and double cluster standard errors by 3rd grade school by year and student $(* \mathrm{p}<.10 * * \mathrm{p}<.05 * * * \mathrm{p}<.01)$. Class rank is generated by determining the percentile of a student's academic index in the distribution of scores in their school in that year and grade. Class rank is measured between the 0th and 99th percentile, with larger numbers indicating the higher end of the score distribution. Students who are score at least proficient on math and ELA MCAS subjects meet Massachusetts' high school graduation requirement. Students are eligible for the Adams Scholarship if they score at least proficient in both math and ELA, advanced on one of those subjects, and are in the top $25 \%$ of scores in the district. Students without test scores are marked as zeroes for the two indicator variables. 
Table B.8: Fuzzy Regression Discontinuity Estimates of Effects on MCAS Indices (All Years)

\begin{tabular}{|c|c|c|c|}
\hline & $\begin{array}{c}\text { Elementary } \\
\text { School } \\
(1)\end{array}$ & $\begin{array}{c}\text { Middle } \\
\text { School } \\
\quad(2)\end{array}$ & $\begin{array}{c}\text { 10th } \\
\text { Grade } \\
(3)\end{array}$ \\
\hline 2SLS & $\begin{array}{c}0.060 \\
(0.067)\end{array}$ & $\begin{array}{c}-0.017 \\
(0.070)\end{array}$ & $\begin{array}{c}0.036 \\
(0.114)\end{array}$ \\
\hline $\mathrm{CCM}$ & 0.184 & 0.362 & 0.275 \\
\hline N (students) & 14,825 & 11,752 & 6,332 \\
\hline \multicolumn{4}{|c|}{ (B) Black and Latino Students } \\
\hline 2SLS & $\begin{array}{c}0.057 \\
(0.092)\end{array}$ & $\begin{array}{c}0.066 \\
(0.102)\end{array}$ & $\begin{array}{c}0.183 \\
(0.191)\end{array}$ \\
\hline $\mathrm{CCM}$ & 0.165 & 0.267 & 0.085 \\
\hline N (students) & 9,676 & 7,564 & 3,953 \\
\hline \multicolumn{4}{|c|}{ (C) White and Asian Students } \\
\hline 2SLS & $\begin{array}{c}0.079 \\
(0.100)\end{array}$ & $\begin{array}{c}-0.105 \\
(0.103)\end{array}$ & $\begin{array}{c}-0.096 \\
(0.138)\end{array}$ \\
\hline $\mathrm{CCM}$ & 0.224 & 0.512 & 0.499 \\
\hline N (students) & 5,149 & 4,188 & 2,379 \\
\hline
\end{tabular}

Notes: Each coefficient labeled "2SLS" is the fuzzy regression discontinuity estimate of 4th grade AWC attendance on the outcome listed in the column heading. An indicator for scoring above the AWC qualification threshold is the instrument for AWC attendance. The specification uses local linear regression with a triangular kernel of bandwidth 0.65. Listed below each coefficient is the control complier mean (CCM). All regressions include 3rd grade school by year fixed effects and controls for demographic characteristics and baseline status for in subsidized lunch, special education, and English learner. The sample is restricted to 3rd graders enrolled in Boston Public Schools in the fall of 2001 to 2012. The MCAS index is the mean of all available MCAS subject test z-scores, standardized to be mean zero, standard deviation one. Elementary school regressions stack 4th and 5th grade outcomes, include grade fixed effects, and double cluster standard errors by 3rd grade school by year and student. Middle school regressions stack 6th, 7th, and 8th grade outcomes, include grade fixed effects, and double cluster standard errors by 3 rd grade school by year and student $(* \mathrm{p}<.10 * * \mathrm{p}<.05 * * * \mathrm{p}<.01)$. 
Table B.9: Fuzzy Regression Discontinuity Estimates of Effects on Advanced Placement Test Taking and Scores

\begin{tabular}{|c|c|c|c|c|c|c|}
\hline & $\begin{array}{l}\text { Any } \\
\text { AP } \\
(1)\end{array}$ & $\begin{array}{c}\text { Any } \\
\text { English } \\
(2)\end{array}$ & $\begin{array}{c}\text { U.S. Hist } \\
\text { or Gov't } \\
\quad(3)\end{array}$ & $\begin{array}{c}\text { Any } \\
\text { Econ } \\
(4)\end{array}$ & $\begin{array}{c}\text { Any } \\
\text { Science } \\
(5)\end{array}$ & $\begin{array}{c}\text { Any } \\
\text { Calculus } \\
(6)\end{array}$ \\
\hline \multicolumn{7}{|l|}{ (A) Took AP Exam } \\
\hline 2SLS & $\begin{array}{c}0.118 \\
(0.085)\end{array}$ & $\begin{array}{l}-0.046 \\
(0.075)\end{array}$ & $\begin{array}{l}-0.001 \\
(0.071)\end{array}$ & $\begin{array}{l}0.107^{* *} \\
(0.055)\end{array}$ & $\begin{array}{l}-0.042 \\
(0.079)\end{array}$ & $\begin{array}{c}0.021 \\
(0.062)\end{array}$ \\
\hline $\mathrm{CCM}$ & 0.540 & 0.371 & 0.193 & 0.066 & 0.304 & 0.107 \\
\hline \multicolumn{7}{|l|}{ (B) Scored above 2} \\
\hline $2 \mathrm{SLS}$ & $\begin{array}{c}0.062 \\
(0.080)\end{array}$ & $\begin{array}{l}-0.096 \\
(0.073)\end{array}$ & $\begin{array}{c}0.031 \\
(0.068)\end{array}$ & $\begin{array}{c}0.056 \\
(0.048)\end{array}$ & $\begin{array}{l}-0.030 \\
(0.068)\end{array}$ & $\begin{array}{c}0.014 \\
(0.048)\end{array}$ \\
\hline $\mathrm{CCM}$ & 0.487 & 0.365 & 0.149 & 0.064 & 0.206 & 0.074 \\
\hline \multicolumn{7}{|l|}{ (C) Scored above 3} \\
\hline 2SLS & $\begin{array}{c}0.007 \\
(0.079)\end{array}$ & $\begin{array}{l}-0.107^{*} \\
(0.060)\end{array}$ & $\begin{array}{l}-0.022 \\
(0.056)\end{array}$ & $\begin{array}{c}0.048 \\
(0.045)\end{array}$ & $\begin{array}{c}0.010 \\
(0.062)\end{array}$ & $\begin{array}{l}-0.013 \\
(0.042)\end{array}$ \\
\hline $\mathrm{CCM}$ & 0.369 & 0.242 & 0.125 & 0.042 & 0.102 & 0.059 \\
\hline \multicolumn{7}{|l|}{ (D) Scored above 4} \\
\hline $2 \mathrm{SLS}$ & $\begin{array}{c}-0.125^{*} \\
(0.069)\end{array}$ & $\begin{array}{c}-0.101^{* *} \\
(0.042)\end{array}$ & $\begin{array}{l}-0.037 \\
(0.044)\end{array}$ & $\begin{array}{c}0.010 \\
(0.035)\end{array}$ & $\begin{array}{l}-0.039 \\
(0.044)\end{array}$ & $\begin{array}{c}0.014 \\
(0.037)\end{array}$ \\
\hline $\mathrm{CCM}$ & 0.269 & 0.097 & 0.075 & 0.026 & 0.054 & 0.034 \\
\hline $\mathrm{N}$ & 4,671 & 4,671 & 4,671 & 4,671 & 4,671 & 4,671 \\
\hline
\end{tabular}

Notes: Each coefficient labeled "2SLS" is the fuzzy regression discontinuity estimate of 4th grade AWC attendance on the outcome listed in the column heading. An indicator for scoring above the AWC qualification threshold is the instrument for AWC attendance. The specification uses local linear regression with a triangular kernel of bandwidth 0.65. Listed below each coefficient is the control complier mean (CCM). All regressions include 3rd grade year fixed effects. The sample is restricted to 3rd graders enrolled in Boston Public Schools in the fall of 2001 to 2005 . Robust standard errors clustered by 3rd grade school by year are in parentheses $\left(* \mathrm{p}<.10^{* *} \mathrm{p}<.05\right.$ $* * * \mathrm{p}<.01)$. 
Table B.10: Fuzzy Regression Discontinuity Estimates of Effects on SAT Test Taking and Scores

\begin{tabular}{|c|c|c|c|c|}
\hline & $\begin{array}{c}\text { Composite } \\
(2400) \\
(1)\end{array}$ & $\begin{array}{c}\text { Verbal } \\
(800) \\
(2)\end{array}$ & $\begin{array}{c}\text { Math } \\
(800) \\
(3)\end{array}$ & $\begin{array}{c}\text { Writing } \\
(800) \\
(4)\end{array}$ \\
\hline \multicolumn{5}{|l|}{ (A) Took SAT } \\
\hline 2SLS & $\begin{array}{c}0.058 \\
(0.059)\end{array}$ & & & \\
\hline $\mathrm{CCM}$ & 0.820 & & & \\
\hline \multicolumn{5}{|l|}{ (B) Scored above MA Median } \\
\hline 2SLS & $\begin{array}{c}0.031 \\
(0.083)\end{array}$ & $\begin{array}{l}-0.017 \\
(0.079)\end{array}$ & $\begin{array}{c}0.001 \\
(0.084)\end{array}$ & $\begin{array}{c}0.077 \\
(0.080)\end{array}$ \\
\hline $\mathrm{CCM}$ & 0.427 & 0.435 & 0.600 & 0.350 \\
\hline $\mathrm{N}$ & 4,671 & 4,671 & 4,671 & 4,671 \\
\hline \multicolumn{5}{|l|}{ (C) Average score (for Takers) } \\
\hline 2SLS & $\begin{array}{l}-43.662 \\
(38.057)\end{array}$ & $\begin{array}{c}-17.200 \\
(14.430)\end{array}$ & $\begin{array}{l}-15.595 \\
(15.819)\end{array}$ & $\begin{array}{l}-10.867 \\
(14.345)\end{array}$ \\
\hline $\mathrm{CCM}$ & 1565 & 511 & 556 & 499 \\
\hline $\mathrm{N}$ & 3,844 & 3,844 & 3,844 & 3,844 \\
\hline
\end{tabular}

Notes: Each coefficient labeled "2SLS" is the fuzzy regression discontinuity estimate of 4th grade AWC attendance on the outcome listed in the column heading. An indicator for scoring above the AWC qualification threshold is the instrument for AWC attendance. The specification uses local linear regression with a triangular kernel of bandwidth 0.65. Listed below each coefficient is the control complier mean (CCM). All regressions include 3rd grade year fixed effects. The sample is restricted to 3rd graders enrolled in Boston Public Schools in the fall of 2001 to 2005 . Robust standard errors clustered by 3 rd grade school by year are in parentheses $\left({ }^{*} \mathrm{p}<.10^{* *} \mathrm{p}<.05\right.$ $* * * \mathrm{p}<.01)$. 


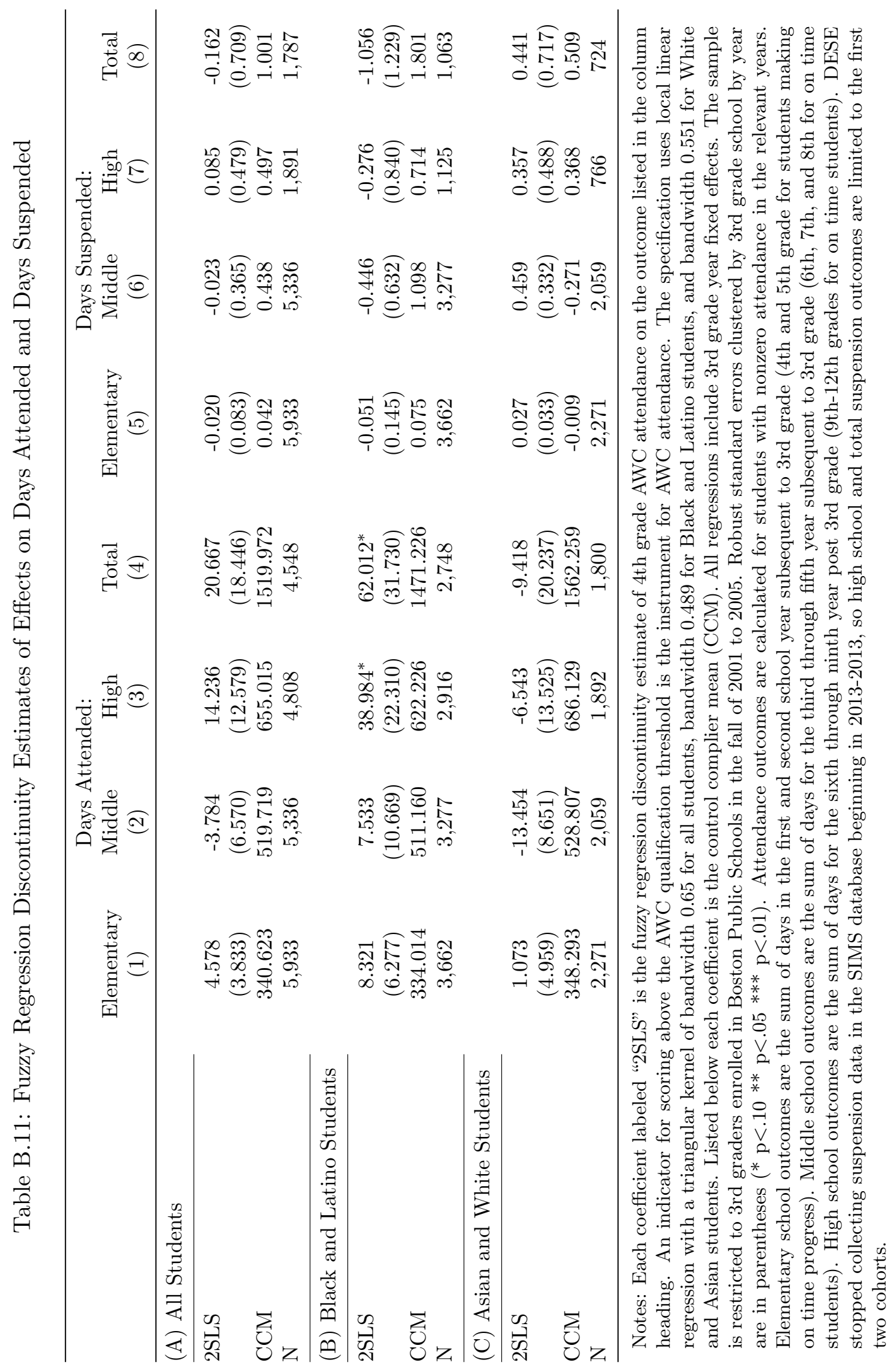


Table B.12: Fuzzy Regression Discontinuity Estimates of Effects on On Time Grade Progress

\begin{tabular}{|c|c|c|c|c|c|c|}
\hline & \multicolumn{5}{|c|}{ On Time Enrollment in Grade: } & \multirow{2}{*}{$\begin{array}{c}\text { On Time } 12 \text { th \& } \\
\text { MCAS Grad. Req } \\
(6)\end{array}$} \\
\hline & $\begin{array}{c}8 \\
(1)\end{array}$ & $\begin{array}{c}9 \\
(2)\end{array}$ & $\begin{array}{l}10 \\
(3)\end{array}$ & $\begin{array}{l}11 \\
(4)\end{array}$ & $\begin{array}{l}12 \\
(5)\end{array}$ & \\
\hline \multicolumn{7}{|c|}{ (A) All Students } \\
\hline 2SLS & $\begin{array}{c}0.005 \\
(0.029)\end{array}$ & $\begin{array}{l}-0.013 \\
(0.040)\end{array}$ & $\begin{array}{c}0.023 \\
(0.050)\end{array}$ & $\begin{array}{c}0.062 \\
(0.046)\end{array}$ & $\begin{array}{c}0.018 \\
(0.036)\end{array}$ & $\begin{array}{l}0.131^{* *} \\
(0.052)\end{array}$ \\
\hline $\mathrm{CCM}$ & 0.966 & 0.946 & 0.901 & 0.877 & 0.926 & 0.820 \\
\hline $\mathrm{N}$ & 5,488 & 5,375 & 5,098 & 4,784 & 4,671 & 4,540 \\
\hline \multicolumn{7}{|c|}{ (B) Black and Latino Students } \\
\hline 2SLS & $\begin{array}{l}-0.007 \\
(0.045)\end{array}$ & $\begin{array}{l}-0.002 \\
(0.062)\end{array}$ & $\begin{array}{c}0.044 \\
(0.077)\end{array}$ & $\begin{array}{c}0.062 \\
(0.071)\end{array}$ & $\begin{array}{c}0.075 \\
(0.055)\end{array}$ & $\begin{array}{l}0.194^{* *} \\
(0.082)\end{array}$ \\
\hline $\mathrm{CCM}$ & 0.975 & 0.924 & 0.878 & 0.889 & 0.888 & 0.760 \\
\hline $\mathrm{N}$ & 3,371 & 3,303 & 3,110 & 2,882 & 2,814 & 2,714 \\
\hline \multicolumn{7}{|c|}{ (C) Asian and White Students } \\
\hline 2 SLS & $\begin{array}{c}0.022 \\
(0.037)\end{array}$ & $\begin{array}{l}-0.027 \\
(0.047)\end{array}$ & $\begin{array}{c}0.002 \\
(0.061)\end{array}$ & $\begin{array}{c}0.066 \\
(0.056)\end{array}$ & $\begin{array}{l}-0.036 \\
(0.045)\end{array}$ & $\begin{array}{c}0.087 \\
(0.066)\end{array}$ \\
\hline $\mathrm{CCM}$ & 0.951 & 0.969 & 0.929 & 0.868 & 0.972 & 0.870 \\
\hline $\mathrm{N}$ & 2,117 & 2,072 & 1,988 & 1,902 & 1,857 & 1,826 \\
\hline
\end{tabular}

Notes: Each coefficient labeled "2SLS" is the fuzzy regression discontinuity estimate of 4th grade AWC attendance on the outcome listed in the column heading. An indicator for scoring above the AWC qualification threshold is the instrument for AWC attendance. The specification uses local linear regression with a triangular kernel of bandwidth 0.65. Listed below each coefficient is the control complier mean (CCM). All regressions include 3rd grade year fixed effects. The sample is restricted to 3rd graders enrolled in Boston Public Schools in the fall of 2001 to 2005 . Robust standard errors clustered by 3rd grade school by year are in parentheses $(* \mathrm{p}<.10 * * \mathrm{p}<.05$ *** $\mathrm{p}<.01)$. The outcome in the final column is an indicator for both on time enrollment in grade 12 and meeting Massachusetts' MCAS high school graduation requirement for students present in the data in both 10th and 12 th grade. 


\section{Results for Additional Subgroups}


Table C.1: Fuzzy Regression Discontinuity Estimates of Effects on MCAS Indices for Additional Subgroups

\begin{tabular}{|c|c|c|c|}
\hline & $\begin{array}{c}\text { Elementary } \\
\text { School } \\
(1)\end{array}$ & $\begin{array}{c}\text { Middle } \\
\text { School } \\
(2)\end{array}$ & $\begin{array}{c}10 \text { th } \\
\text { Grade } \\
(3)\end{array}$ \\
\hline \multicolumn{4}{|c|}{ (A) All Students } \\
\hline 2 SLS & $\begin{array}{c}0.058 \\
(0.078)\end{array}$ & $\begin{array}{c}0.041 \\
(0.079)\end{array}$ & $\begin{array}{c}0.149 \\
(0.113)\end{array}$ \\
\hline $\begin{array}{l}\text { CCM } \\
\mathrm{N} \text { (students) }\end{array}$ & $\begin{array}{l}0.228 \\
6,161\end{array}$ & $\begin{array}{l}0.363 \\
5,741\end{array}$ & $\begin{array}{l}0.226 \\
5,209\end{array}$ \\
\hline \multicolumn{4}{|c|}{ (B) Low-Income Students } \\
\hline 2SLS & $\begin{array}{c}0.050 \\
(0.091)\end{array}$ & $\begin{array}{c}0.072 \\
(0.090)\end{array}$ & $\begin{array}{c}0.130 \\
(0.139)\end{array}$ \\
\hline $\begin{array}{l}\text { CCM } \\
\mathrm{N} \text { (students) }\end{array}$ & $\begin{array}{l}0.169 \\
4,733\end{array}$ & $\begin{array}{l}0.320 \\
4,418\end{array}$ & $\begin{array}{l}0.206 \\
4,016\end{array}$ \\
\hline \multicolumn{4}{|c|}{ (C) Non-Low-Income Students } \\
\hline 2 SLS & $\begin{array}{c}0.115 \\
(0.163)\end{array}$ & $\begin{array}{c}0.001 \\
(0.171)\end{array}$ & $\begin{array}{c}0.311 \\
(0.220)\end{array}$ \\
\hline $\begin{array}{l}\text { CCM } \\
\mathrm{N} \text { (students) }\end{array}$ & $\begin{array}{l}0.381 \\
1,428\end{array}$ & $\begin{array}{l}0.447 \\
1,323\end{array}$ & $\begin{array}{l}0.197 \\
1,193\end{array}$ \\
\hline \multicolumn{4}{|c|}{ (D) High MCAS Students } \\
\hline 2 2SLS & $\begin{array}{c}0.005 \\
(0.096)\end{array}$ & $\begin{array}{l}-0.056 \\
(0.104)\end{array}$ & $\begin{array}{l}-0.019 \\
(0.154)\end{array}$ \\
\hline $\begin{array}{l}\text { CCM } \\
\mathrm{N} \text { (students) }\end{array}$ & $\begin{array}{l}0.402 \\
3,096\end{array}$ & $\begin{array}{l}0.525 \\
2,858\end{array}$ & $\begin{array}{l}0.454 \\
2,590\end{array}$ \\
\hline \multicolumn{4}{|c|}{ (E) Low MCAS Students } \\
\hline 2SLS & $\begin{array}{c}0.063 \\
(0.127)\end{array}$ & $\begin{array}{c}0.115 \\
(0.128)\end{array}$ & $\begin{array}{l}0.308^{*} \\
(0.166)\end{array}$ \\
\hline $\mathrm{CCM}$ & 0.077 & 0.238 & 0.013 \\
\hline N (students) & 3,018 & 2,835 & 2,573 \\
\hline
\end{tabular}

Notes: Each coefficient labeled "2SLS" is the fuzzy regression discontinuity estimate of 4 th grade AWC attendance on the outcome listed in the column heading. An indicator for scoring above the AWC qualification threshold is the instrument for AWC attendance. The specification uses local linear regression with a triangular kernel of of bandwidth 0.65. High MCAS students are defined as those who score $0.25 \sigma$ or higher on their 3rd grade ELA MCAS; lower MCAS students are those who score below that threshold. Listed below each coefficient is the control complier mean (CCM). All regressions include 3rd grade year fixed effects. The sample is restricted to 3rd graders enrolled in Boston Public Schools in the fall of 2001 to 2005. The MCAS index is the mean of all available MCAS subject test z-scores, standardized to be mean zero, standard deviation one. Elementary school regressions stack 4th and 5th grade outcomes, include grade fixed effects, and double cluster standard errors by 3 rd grade school by year and student. Middle school regressions stack 6th, 7th, and 8th grade outcomes, include grade fixed effects, and double cluster standard errors by 3rd grade school by year and student $(* \mathrm{p}<.10 * * \mathrm{p}<.05$ $* * * \mathrm{p}<.01)$. 
Table C.2: Fuzzy Regression Discontinuity Estimates of Effects on Academic Outcomes for Additional Subgroups

\begin{tabular}{|c|c|c|c|c|c|c|c|}
\hline & $\begin{array}{c}\text { Algebra } 1 \\
\text { by } 8 \text { th } \\
(1)\end{array}$ & $\begin{array}{c}\text { Took } \\
\text { Any AP } \\
(2)\end{array}$ & $\begin{array}{c}\text { \# APs } \\
\text { Taken } \\
(3)\end{array}$ & $\begin{array}{l}\text { Took } \\
\text { SAT } \\
(4)\end{array}$ & $\begin{array}{c}\text { SAT } \\
\text { Score } \\
(5)\end{array}$ & $\begin{array}{c}\text { On Time } \\
\text { HS Grad. } \\
\quad(6)\end{array}$ & $\begin{array}{c}\text { Late } \\
\text { HS Grad } \\
(7)\end{array}$ \\
\hline \multicolumn{8}{|c|}{ (A) All Students } \\
\hline 2SLS & $\begin{array}{l}0.254^{*} \\
(0.131)\end{array}$ & $\begin{array}{c}0.118 \\
(0.085)\end{array}$ & $\begin{array}{c}0.075 \\
(0.354)\end{array}$ & $\begin{array}{c}0.058 \\
(0.059)\end{array}$ & $\begin{array}{c}-43.662 \\
(38.057)\end{array}$ & $\begin{array}{c}0.081 \\
(0.059)\end{array}$ & $\begin{array}{c}0.034 \\
(0.044)\end{array}$ \\
\hline $\mathrm{CCM}$ & 0.505 & 0.540 & 1.546 & 0.820 & 1565.433 & 0.810 & 0.912 \\
\hline $\mathrm{N}$ & 4,456 & 4,671 & 4,671 & 4,671 & 3,844 & 4,671 & 3,771 \\
\hline \multicolumn{8}{|c|}{ (A) Low-Income Students } \\
\hline 2SLS & $\begin{array}{c}0.121 \\
(0.153)\end{array}$ & $\begin{array}{c}0.130 \\
(0.095)\end{array}$ & $\begin{array}{c}0.124 \\
(0.414)\end{array}$ & $\begin{array}{c}0.043 \\
(0.068)\end{array}$ & $\begin{array}{c}-5.265 \\
(39.510)\end{array}$ & $\begin{array}{l}0.115^{*} \\
(0.067)\end{array}$ & $\begin{array}{c}0.046 \\
(0.053)\end{array}$ \\
\hline $\mathrm{CCM}$ & 0.645 & 0.548 & 1.641 & 0.828 & 1524.262 & 0.771 & 0.895 \\
\hline $\mathrm{N}$ & 3,342 & 3,543 & 3,543 & 3,543 & 2,870 & 3,543 & 2,844 \\
\hline \multicolumn{8}{|c|}{ (C) Not Low-Income Students } \\
\hline 2SLS & $\begin{array}{l}1.004^{* *} \\
(0.425)\end{array}$ & $\begin{array}{c}0.096 \\
(0.176)\end{array}$ & $\begin{array}{l}-0.076 \\
(0.761)\end{array}$ & $\begin{array}{c}0.135 \\
(0.131)\end{array}$ & $\begin{array}{r}-124.345 \\
(94.604)\end{array}$ & $\begin{array}{l}-0.027 \\
(0.117)\end{array}$ & $\begin{array}{c}0.013 \\
(0.068)\end{array}$ \\
\hline $\mathrm{CCM}$ & -0.270 & 0.480 & 1.113 & 0.771 & 1662.115 & 0.942 & 0.962 \\
\hline $\mathrm{N}$ & 1,114 & 1,128 & 1,128 & 1,128 & 974 & 1,128 & 927 \\
\hline \multicolumn{8}{|c|}{ (D) High MCAS Students } \\
\hline 2SLS & $\begin{array}{c}0.225 \\
(0.196)\end{array}$ & $\begin{array}{c}0.078 \\
(0.109)\end{array}$ & $\begin{array}{c}0.193 \\
(0.473)\end{array}$ & $\begin{array}{l}-0.074 \\
(0.080)\end{array}$ & $\begin{array}{l}-23.135 \\
(46.715)\end{array}$ & $\begin{array}{c}0.017 \\
(0.086)\end{array}$ & $\begin{array}{l}-0.005 \\
(0.061)\end{array}$ \\
\hline $\mathrm{CCM}$ & 0.581 & 0.596 & 1.498 & 0.939 & 1571.832 & 0.878 & 0.961 \\
\hline $\mathrm{N}$ & 2,163 & 2,384 & 2,384 & 2,384 & 2,053 & 2,384 & 1,948 \\
\hline \multicolumn{8}{|c|}{ (E) Low MCAS Students } \\
\hline 2SLS & $\begin{array}{c}0.217 \\
(0.202)\end{array}$ & $\begin{array}{c}0.099 \\
(0.133)\end{array}$ & $\begin{array}{l}-0.253 \\
(0.498)\end{array}$ & $\begin{array}{c}0.253^{* * *} \\
(0.096)\end{array}$ & $\begin{array}{l}-66.472 \\
(60.158)\end{array}$ & $\begin{array}{l}0.157^{*} \\
(0.087)\end{array}$ & $\begin{array}{c}0.075 \\
(0.070)\end{array}$ \\
\hline $\mathrm{CCM}$ & 0.496 & 0.546 & 1.837 & 0.641 & 1567.942 & 0.720 & 0.845 \\
\hline $\mathrm{N}$ & 2,272 & 2,247 & 2,247 & 2,247 & 1,760 & 2,247 & 1,787 \\
\hline
\end{tabular}

Notes: Each coefficient labeled "2SLS" is the fuzzy regression discontinuity estimate of 4th grade AWC attendance on the outcome listed in the column heading. An indicator for scoring above the AWC qualification threshold is the instrument for AWC attendance. The specification uses local linear regression with a triangular kernel of of bandwidth 0.65. High MCAS students are defined as those who score $0.25 \sigma$ or higher on their 3rd grade ELA MCAS; lower MCAS students are those who score below that threshold. Listed below each coefficient is the control complier mean (CCM). All regressions include 3rd grade year fixed effects. The sample is restricted to 3rd graders enrolled in Boston Public Schools in the fall of 2001 to 2005. Robust standard errors clustered by 3rd grade school by year are in parentheses $(* \mathrm{p}<.10 * * \mathrm{p}<.05 * * * \mathrm{p}<.01)$. For Algebra 1 by 8 th grade, the sample to students who match to the student course data (2011-2014), which are the fall cohorts from 2005-2008. On time high school graduation is an indicator for high school graduation 10 years after the third grade exam for AWC eligibility; late high school graduation is an indicator for 11 years after. 
Table C.3: Fuzzy Regression Discontinuity Estimates of Effects on On Time Grade Progress for Additional Subgroups

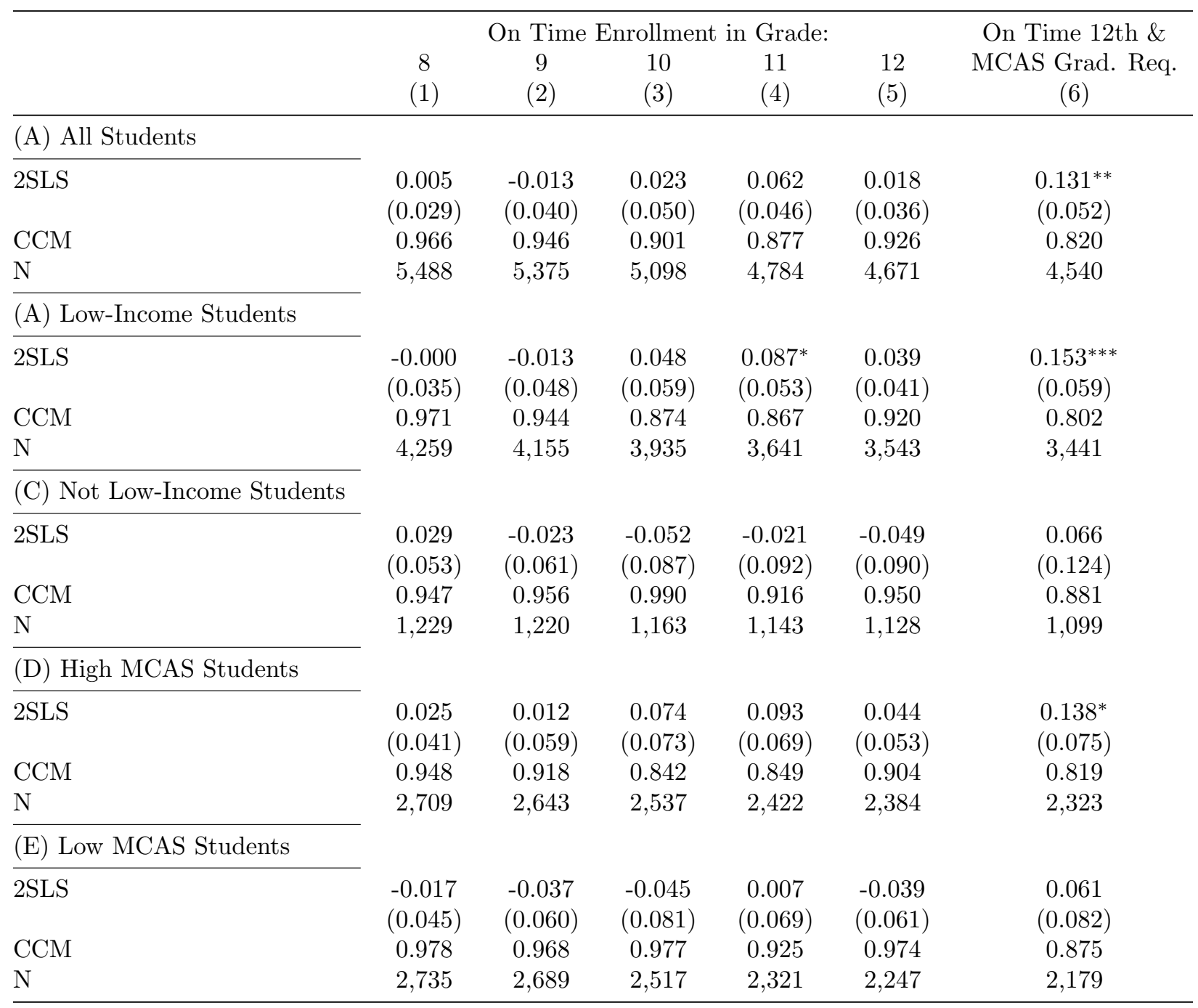

Notes: Each coefficient labeled "2SLS" is the fuzzy regression discontinuity estimate of 4th grade AWC attendance on the outcome listed in the column heading. An indicator for scoring above the AWC qualification threshold is the instrument for AWC attendance. The specification uses local linear regression with a triangular kernel of of bandwidth 0.65. High MCAS students are defined as those who score $0.25 \sigma$ or higher on their 3rd grade ELA MCAS; lower MCAS students are those who score below that threshold. Listed below each coefficient is the control complier mean (CCM). All regressions include 3rd grade year fixed effects. The sample is restricted to 3rd graders enrolled in Boston Public Schools in the fall of 2001 to 2005. Robust standard errors clustered by 3rd grade school by year are in parentheses $\left(* \mathrm{p}<.10^{* *} \mathrm{p}<.05 * * * \mathrm{p}<.01\right)$. The outcome in the final column is an indicator for both on time enrollment in grade 12 and meeting Massachusetts' MCAS high school graduation requirement for students present in the data in both 10 th and 12 th grade. 
Table C.4: Fuzzy Regression Discontinuity Estimates of Effects on College for Additional Subgroups

\begin{tabular}{|c|c|c|c|c|c|}
\hline & \multicolumn{3}{|c|}{ On Time College Enrollment: } & \multirow{2}{*}{$\begin{array}{c}\text { College } \\
\text { Quality } \\
\$ 2014 \\
(4)\end{array}$} & \multirow{2}{*}{$\begin{array}{c}\text { Late } \\
\text { Enrollment } \\
\text { Any } \\
(5)\end{array}$} \\
\hline & $\begin{array}{l}\text { Any } \\
(1)\end{array}$ & $\begin{array}{c}\text { Four-year } \\
(2)\end{array}$ & $\begin{array}{c}\text { Two-year } \\
(3)\end{array}$ & & \\
\hline \multicolumn{6}{|c|}{ (A) All Students } \\
\hline 2SLS & $\begin{array}{l}0.149^{*} \\
(0.080)\end{array}$ & $\begin{array}{c}0.063 \\
(0.081)\end{array}$ & $\begin{array}{l}0.087^{*} \\
(0.045)\end{array}$ & $\begin{array}{c}1788.007 \\
(3866.399)\end{array}$ & $\begin{array}{c}0.169^{* *} \\
(0.084)\end{array}$ \\
\hline $\mathrm{CCM}$ & 0.532 & 0.522 & 0.009 & 43653.586 & 0.548 \\
\hline $\mathrm{N}$ & 5,502 & 5,502 & 5,502 & 5,502 & 4,567 \\
\hline \multicolumn{6}{|c|}{ (B) Low-Income Students } \\
\hline 2SLS & $\begin{array}{c}0.141 \\
(0.089)\end{array}$ & $\begin{array}{c}0.065 \\
(0.091)\end{array}$ & $\begin{array}{l}0.076 \\
(0.053)\end{array}$ & $\begin{array}{c}96.222 \\
(4451.520)\end{array}$ & $\begin{array}{c}0.148 \\
(0.093)\end{array}$ \\
\hline $\mathrm{CCM}$ & 0.574 & 0.544 & 0.029 & 46208.528 & 0.611 \\
\hline $\mathrm{N}$ & 4,189 & 4,189 & 4,189 & 4,189 & 3,473 \\
\hline \multicolumn{6}{|c|}{ (C) Not Low-Income Students } \\
\hline 2SLS & $\begin{array}{c}0.226 \\
(0.163)\end{array}$ & $\begin{array}{c}0.100 \\
(0.164)\end{array}$ & $\begin{array}{c}0.126 \\
(0.080)\end{array}$ & $\begin{array}{c}8684.839 \\
(8519.128)\end{array}$ & $\begin{array}{l}0.299^{*} \\
(0.158)\end{array}$ \\
\hline $\mathrm{CCM}$ & 0.373 & 0.427 & -0.054 & 34973.373 & 0.310 \\
\hline $\mathrm{N}$ & 1,313 & 1,313 & 1,313 & 1,313 & 1,094 \\
\hline \multicolumn{6}{|c|}{ (D) High MCAS Students } \\
\hline 2SLS & $\begin{array}{c}0.148 \\
(0.103)\end{array}$ & $\begin{array}{c}0.058 \\
(0.103)\end{array}$ & $\begin{array}{l}0.090^{*} \\
(0.054)\end{array}$ & $\begin{array}{l}8451.068^{*} \\
(4885.616)\end{array}$ & $\begin{array}{c}0.159 \\
(0.104)\end{array}$ \\
\hline $\mathrm{CCM}$ & 0.539 & 0.514 & 0.025 & 37204.101 & 0.570 \\
\hline $\mathrm{N}$ & 2,756 & 2,756 & 2,756 & 2,756 & 2,299 \\
\hline \multicolumn{6}{|c|}{ (E) Low MCAS Students } \\
\hline 2SLS & $\begin{array}{c}0.174 \\
(0.134)\end{array}$ & $\begin{array}{c}0.092 \\
(0.131)\end{array}$ & $\begin{array}{c}0.083 \\
(0.074)\end{array}$ & $\begin{array}{c}-5177.410 \\
(6772.978)\end{array}$ & $\begin{array}{c}0.229 \\
(0.141)\end{array}$ \\
\hline $\mathrm{CCM}$ & 0.500 & 0.528 & -0.029 & 51100.623 & 0.465 \\
\hline $\mathrm{N}$ & 2,680 & 2,680 & 2,680 & 2,680 & 2,206 \\
\hline
\end{tabular}

Notes: Each coefficient labeled "2SLS" is the fuzzy regression discontinuity estimate of 4 th grade AWC attendance on the outcome listed in the column heading. An indicator for scoring above the AWC qualification threshold is the instrument for AWC attendance. The specification uses local linear regression with a triangular kernel of of bandwidth 0.65. High MCAS students are defined as those who score $0.25 \sigma$ or higher on their 3rd grade ELA MCAS; lower MCAS students are those who score below that threshold. Listed below each coefficient is the control complier mean (CCM). All regressions include 3rd grade year fixed effects. The sample is restricted to 3rd graders enrolled in Boston Public Schools in the fall of 2001 to 2005. Robust standard errors clustered by 3rd grade school by year are in parentheses $\left(* \mathrm{p}<.10^{* *} \mathrm{p}<.05 * * * \mathrm{p}<.01\right)$. On time college entrance is calculated based on entry into college 10 years after the 3rd grade exam for AWC eligibility. Late college entrance is calculated based on entry into college 11 years after the 3rd grade exam for AWC eligibility. College quality earnings outcomes are measured by the estimated 2014 earnings of college attendees from the 1980-1982 birth cohorts from Chetty, et al. (2017). Students are assigned the earnings outcomes of the college they attend, by gender, even if they are not on time attendees. Students who do not attend college are assigned the outcomes for non-attendees of the same gender. 


\section{Results based on 6th Grade Eligibility}

Figure D.1: AWC Enrollment by Distance to Eligibility Threshold (6th Grade)

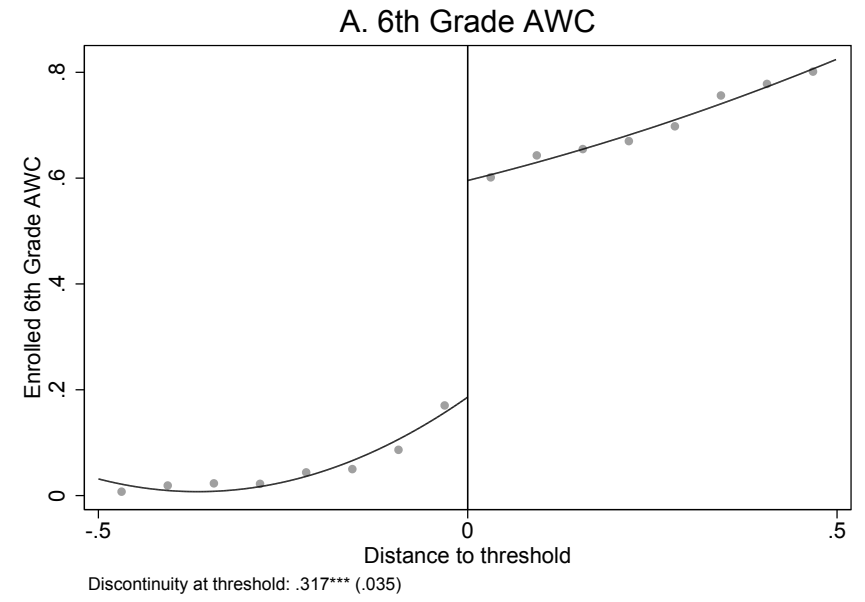

Notes: The above figure shows 6th grade AWC enrollment by the running variable for the 5th grade cohorts from 2001 to 2007 within the bandwidth of 0.5 around the eligibility threshold. A quadratic fit is imposed on either side of the threshold. Each dot represents the average enrollment for a bin of width 0.05 . 
Figure D.2: Distribution of Scores near the Threshold (6th Grade)
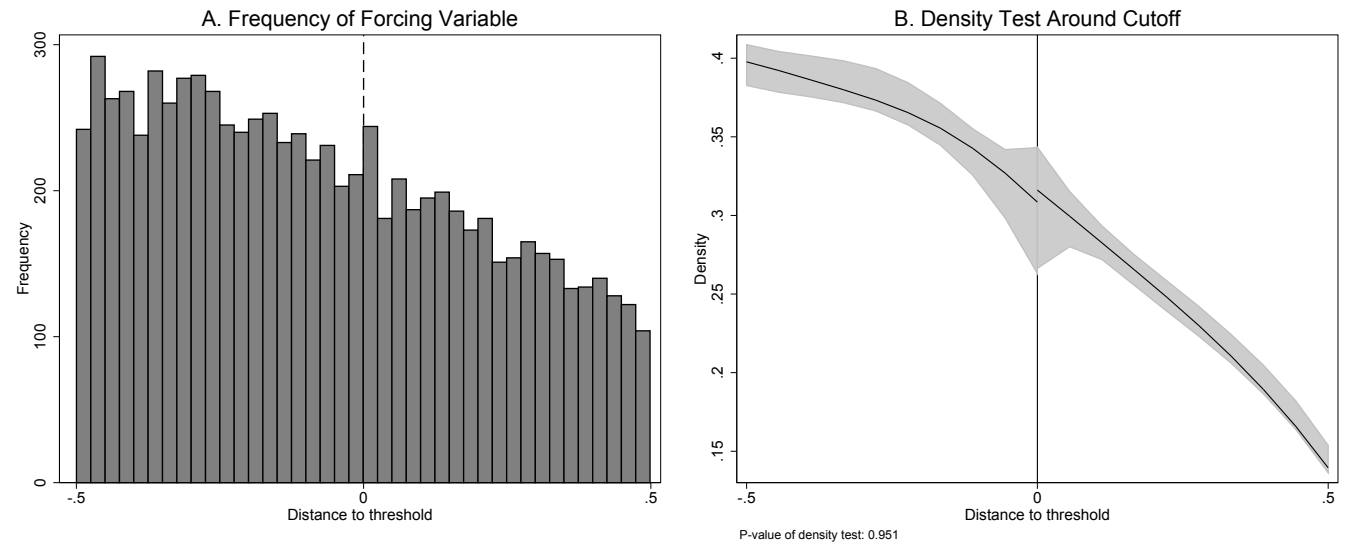

Notes: The above figure shows the distribution of the running variable for the 5 th grade cohorts from 2001 to 2007 within the bandwidth of 1 around the eligibility threshold. The running variable is the distance of a student's combined math and reading Stanford 9 scores from a given year's AWC threshold. Panel A shows the frequency of scores, and Panel B shows a density test at the threshold from Catteneo et al. (2017). 
Figure D.3: Covariate Balance (6th Grade)
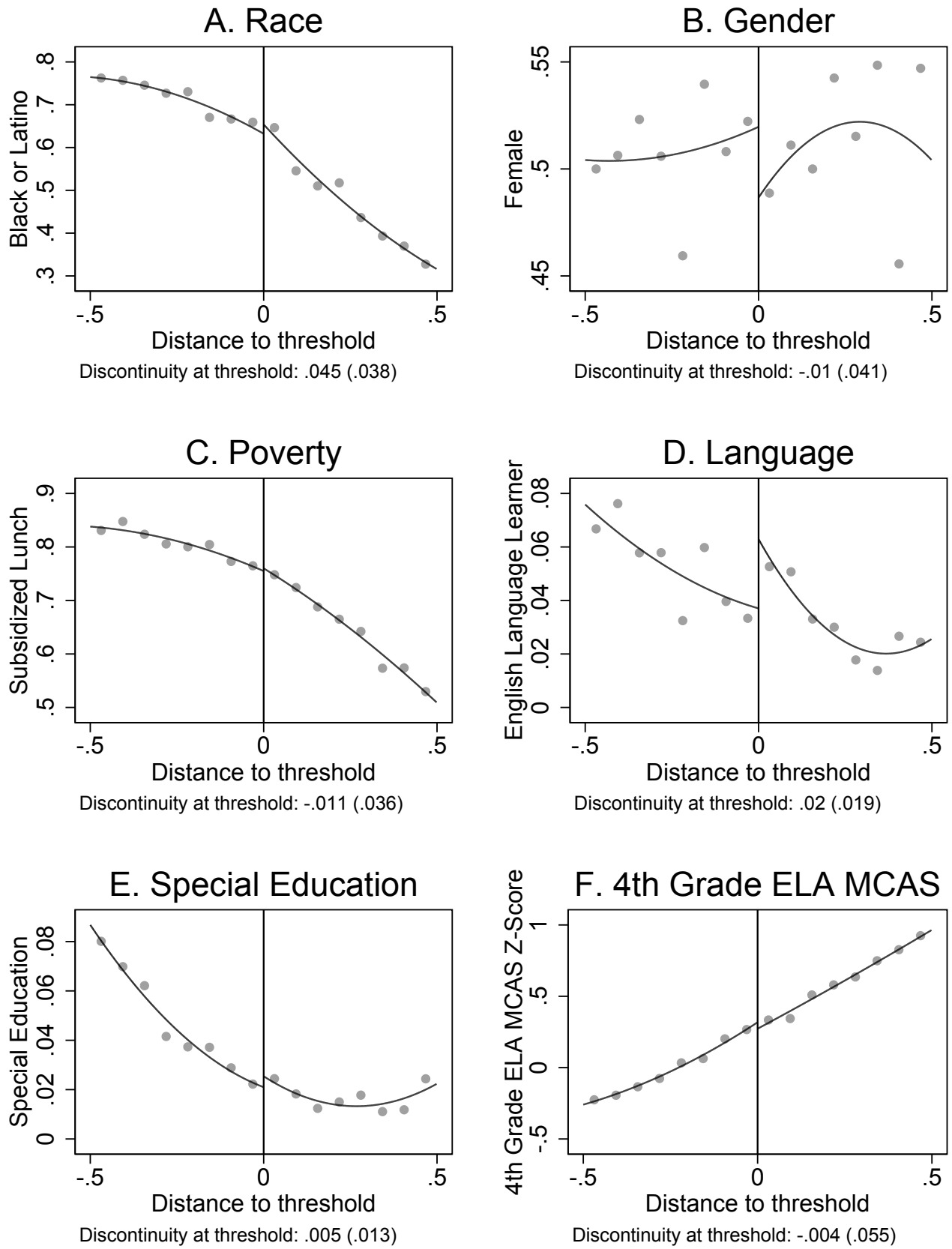

Notes: The above figure shows descriptive characteristics of students by the running variable for the 5 th grade cohorts from 2001 to 2007 within the bandwidth of 0.5. A quadratic fit is imposed on either side of the threshold. Each dot represents the average of the descriptive characteristics for a bin of width 0.05 
Figure D.4: MCAS Outcomes by Distance to Eligbility Threshold (6th Grade)
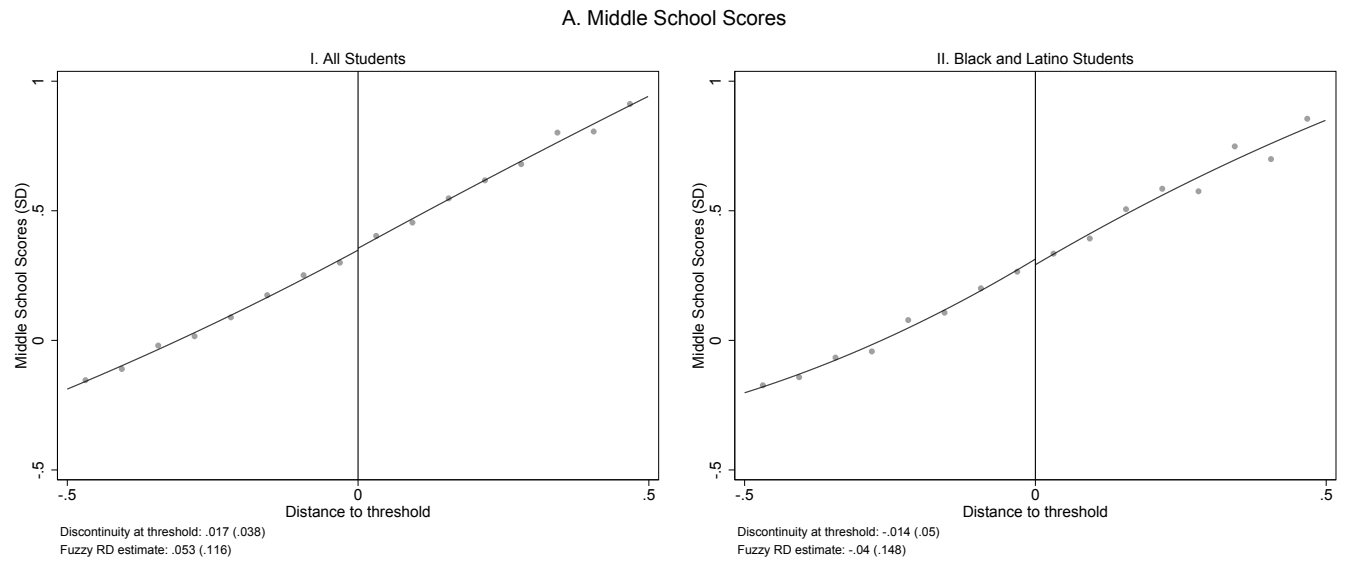

Notes: The above figure shows average MCAS outcomes for bins of width 0.05 on either side of the threshold for all students (left side) and Black and Latino students (right side) within the bandwidth of 0.5 around the eligibility threshold. A quadratic fit is imposed on either side of the threshold. Elementary school scores are the MCAS index for 4th and 5th grade students; middle school scores are the MCAS index for 6th, 7th, and 8th grade students. 
Figure D.5: High School Outcomes by Distance to Eligbility Threshold (6th Grade)

\section{A. Took Any AP Exam}
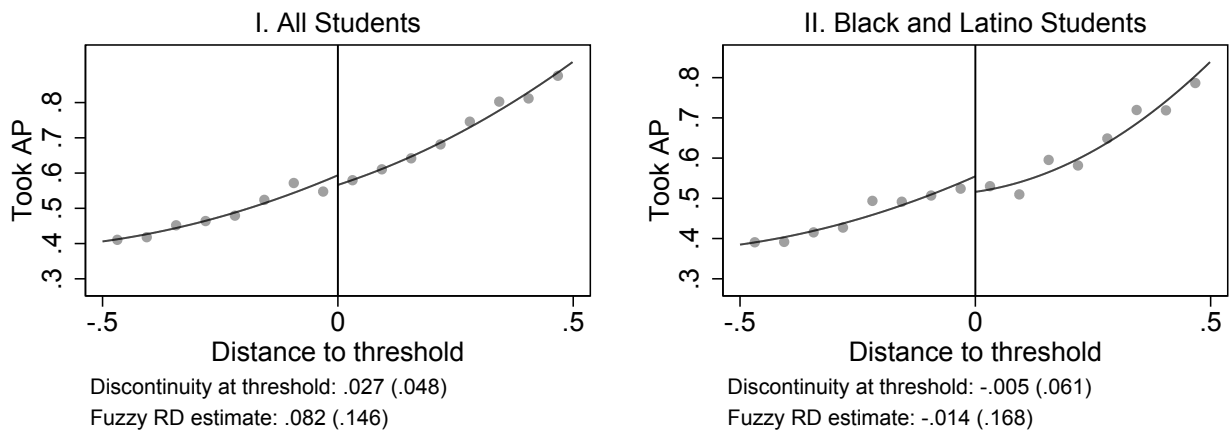

B. SAT Score (2400)
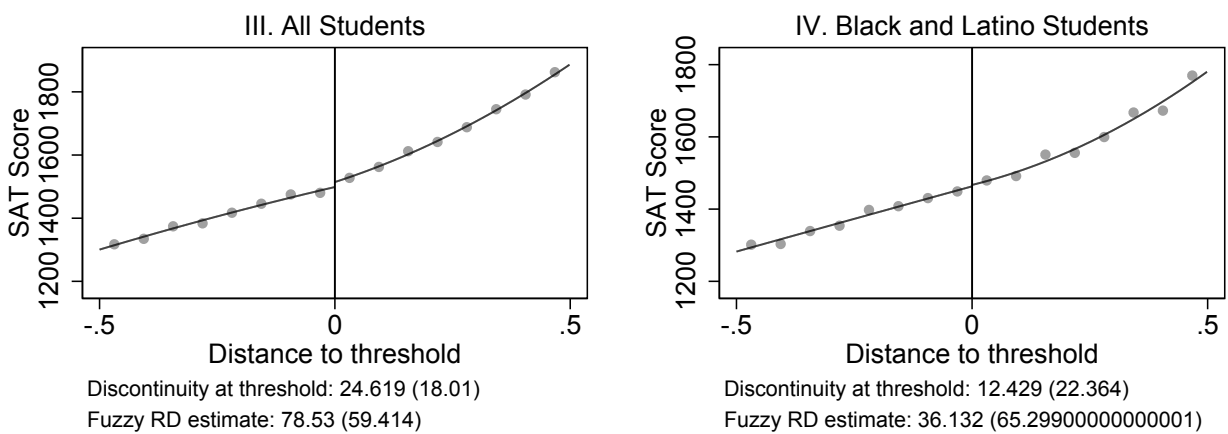

\section{Graduated High School On Time}
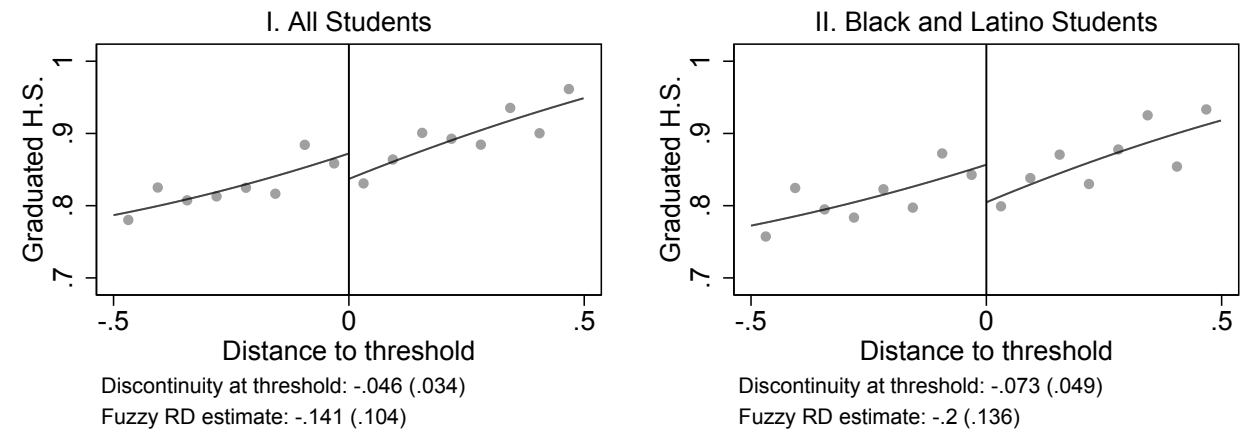

Notes: The above figure shows average high school outcomes for bins of width 0.05 on either side of the threshold for all students (left side) and Black and Latino students (right side) within the bandwidth of 0.5 around the eligibility threshold. A quadratic fit is imposed on either side of the threshold. 
Figure D.6: College Enrollment Outcomes by Distance to Eligbility Threshold (6th Grade)

\section{A. Enrolled Any College On Time}
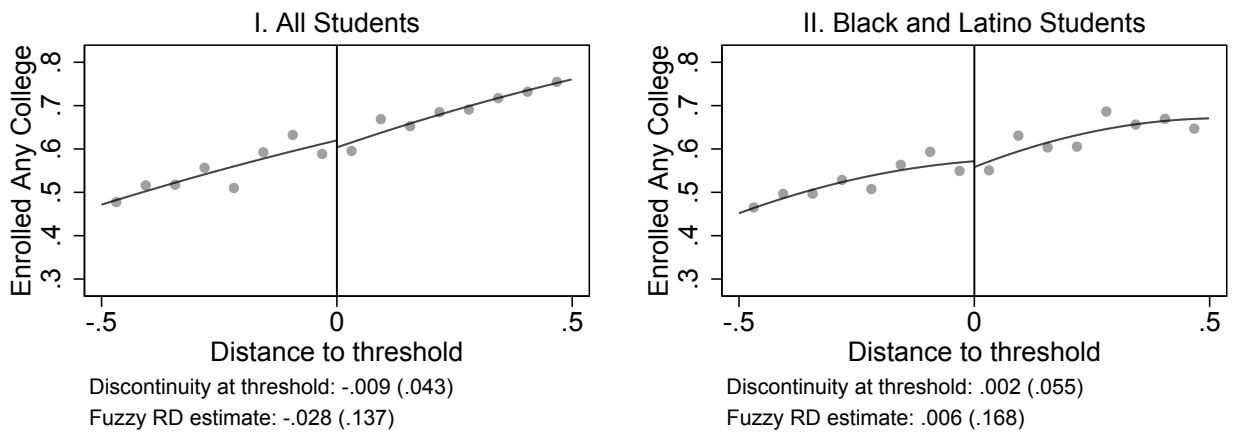

\section{B. Enrolled 4 Year College On Time}
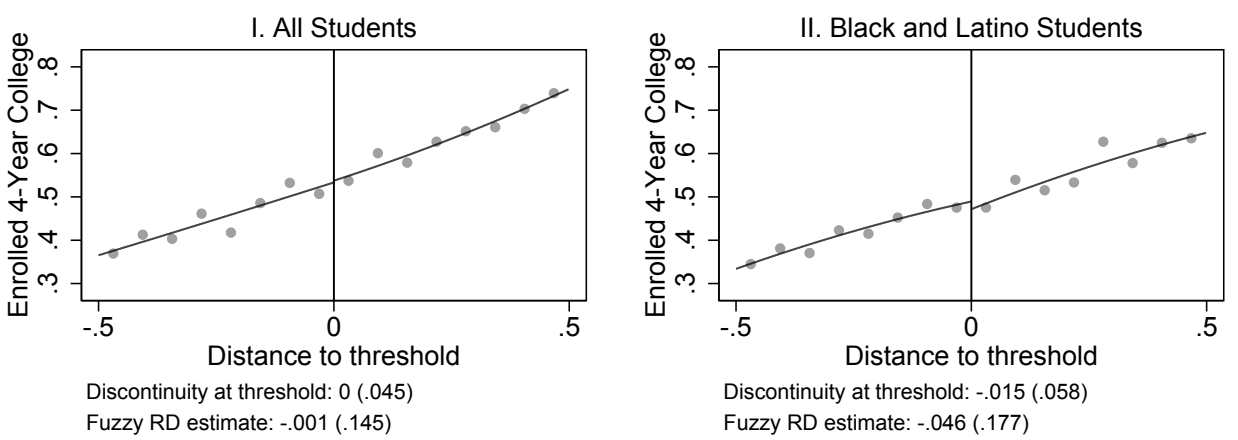

\section{College Quality}
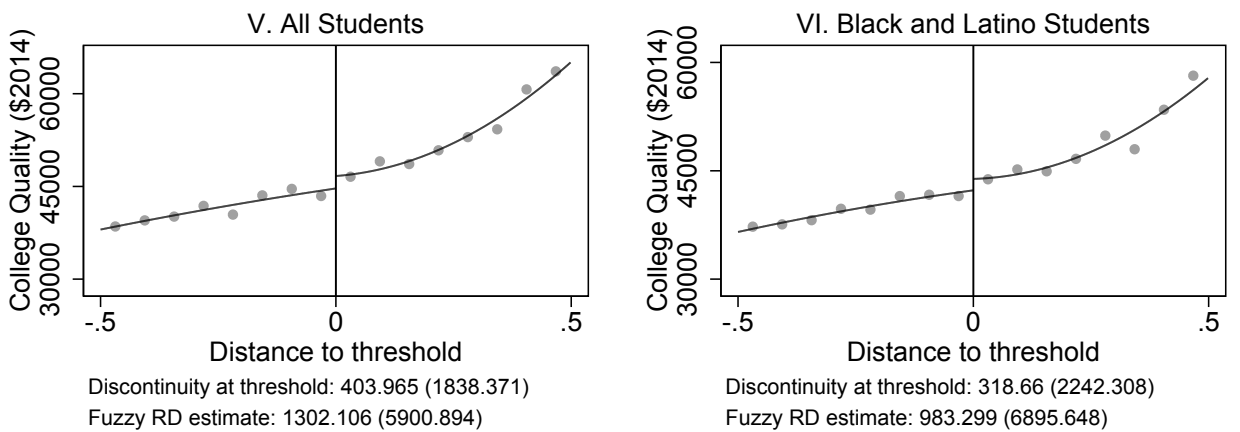

Notes: The above figure shows average college enrollment outcomes for bins of width 0.05 on either side of the threshold for all students (left side) and Black and Latino students (right side) within the bandwidth of 0.5 around the eligibility threshold. A quadratic fit is imposed on either side of the threshold. College quality earnings outcomes are measured by the estimated 2014 earnings of college attendees from the 1980-1982 birth cohorts from Chetty, et al. (2017). Students are assigned the earnings outcomes of the college they attend, by gender, even if they are not on time attendees. Students who do not attend college are assigned the outcomes for non-attendees of the same gender. 
Table D.1: Summary Statistics (6th Grade)

\begin{tabular}{|c|c|c|c|}
\hline & $\begin{array}{c}\text { All } \\
\text { Students } \\
(1)\end{array}$ & $\begin{array}{c}\text { Enrolled in } \\
\text { 6th Grade AWC } \\
\text { (2) }\end{array}$ & $\begin{array}{c}\mathrm{RD} \\
\text { Sample } \\
(3)\end{array}$ \\
\hline \multicolumn{4}{|l|}{ (A) Demographics } \\
\hline Female & 0.482 & 0.529 & 0.509 \\
\hline Black & 0.461 & 0.248 & 0.350 \\
\hline Latino & 0.313 & 0.193 & 0.256 \\
\hline White & 0.122 & 0.265 & 0.196 \\
\hline Asian & 0.091 & 0.278 & 0.181 \\
\hline Other Race & 0.013 & 0.016 & 0.017 \\
\hline Subsidized Lunch & 0.832 & 0.637 & 0.756 \\
\hline English Language Learner & 0.120 & 0.033 & 0.045 \\
\hline 4th Grade ELA & 0.223 & 0.013 & 0.024 \\
\hline Special Education & -0.677 & 0.613 & 0.276 \\
\hline \multicolumn{4}{|l|}{ (B) AWC Enrollment } \\
\hline 6th Grade AWC & 0.107 & 1.000 & 0.355 \\
\hline \multicolumn{4}{|l|}{ (C) MCAS Standardized Index } \\
\hline 4th Grade & -0.541 & 0.829 & 0.458 \\
\hline 10th Grade & -0.482 & 0.649 & 0.329 \\
\hline \multicolumn{4}{|l|}{ (D) High School Milestones } \\
\hline Took Any AP & 0.352 & 0.743 & 0.574 \\
\hline Took SAT & 0.656 & 0.903 & 0.850 \\
\hline On Time H.S. Graduation & 0.728 & 0.899 & 0.855 \\
\hline \multicolumn{4}{|l|}{ (E) On Time College Enrollment } \\
\hline Any College & 0.424 & 0.711 & 0.615 \\
\hline 4-Year College & 0.317 & 0.655 & 0.537 \\
\hline 2-Year College & 0.107 & 0.056 & 0.079 \\
\hline College Quality (\$2014) & 37,410 & 55,121 & 45,793 \\
\hline $\mathrm{N}$ & 27,436 & 2,945 & 2,751 \\
\hline
\end{tabular}

Notes: Mean values of each variable are shown by sample. Column (1) is the full sample of 5 th graders enrolled in BPS in the fall years from 2001-2007. Column (2) restricts that sample to students enrolled in AWC in 6th grade. Column (3) restricts the full sample to those within 0.363 of the eligibility threshold. College quality earnings outcomes are measured by the estimated 2014 earnings of college attendees from the 1980-1982 birth cohorts from Chetty, et al. (2017). Students are assigned the earnings outcomes of the college they attend, by gender, even if they are not on time attendees. Students who do not attend college are assigned the outcomes for non-attendees of the same gender. 


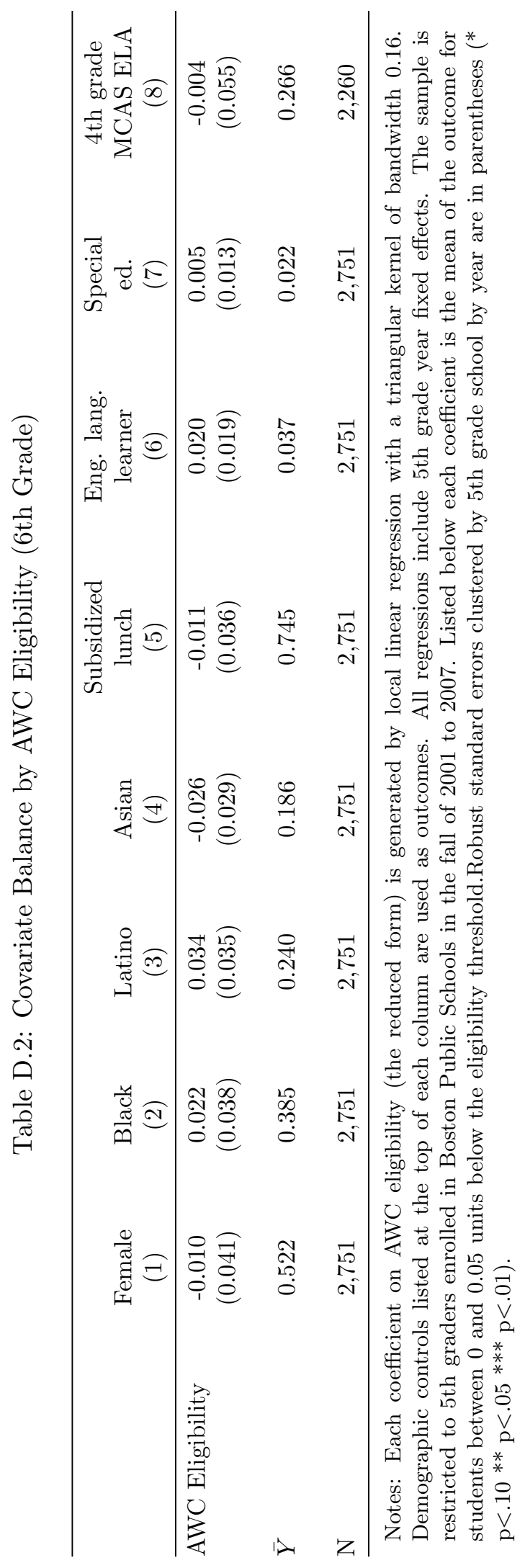




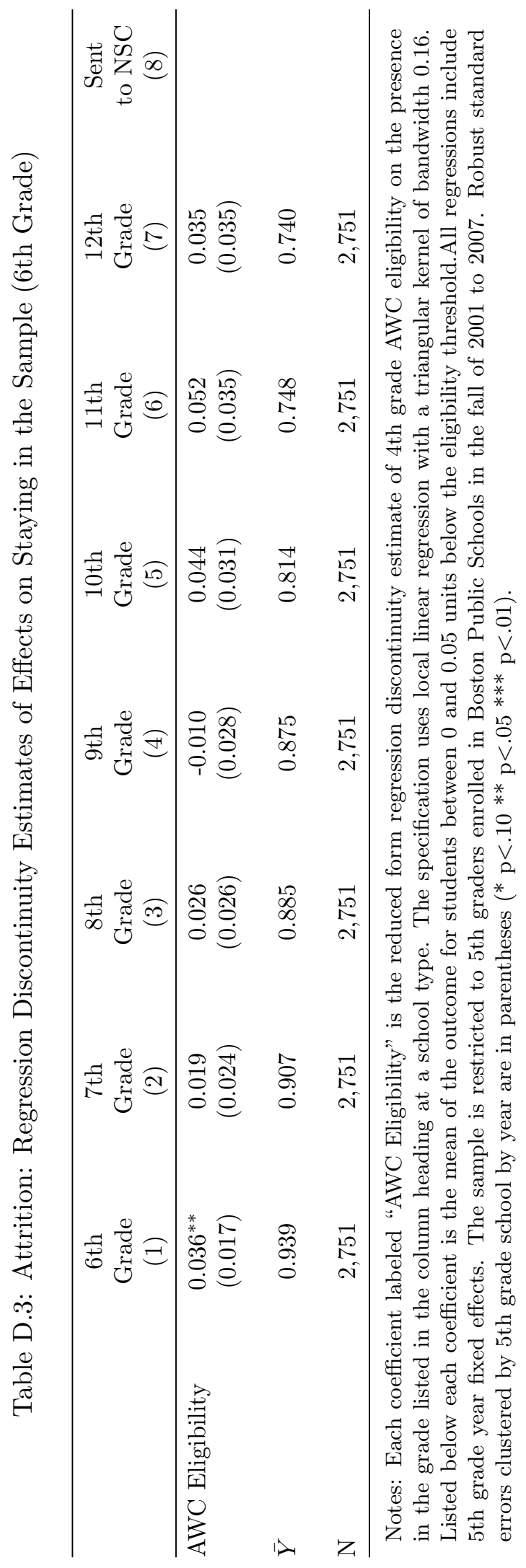


Table D.4: First Stage Estimates of AWC Enrollment (6th Grade)

6th Grade and Above

(1)

6th Grade AWC

$0.317^{* * *}$

$\bar{Y}$

$\mathrm{N}$

2,751

Notes: Robust standard errors clustered by baseline school by year are in parentheses $(* \mathrm{p}<.10 * * \mathrm{p}<.05 * * *$ $\mathrm{p}<.01)$. All regressions include baseline school by year fixed effects and controls for demographic characteristics and baseline program participation. Each coefficient is generated by local linear regression with a triangular kernel of bandwidth 0.16. The sample is restricted to 5th graders enrolled in Boston Public Schools in the fall of 2001 to 2007 . Listed below each coefficient is the mean of the outcome for students between 0 and 0.05 units below the eligibility threshold. 


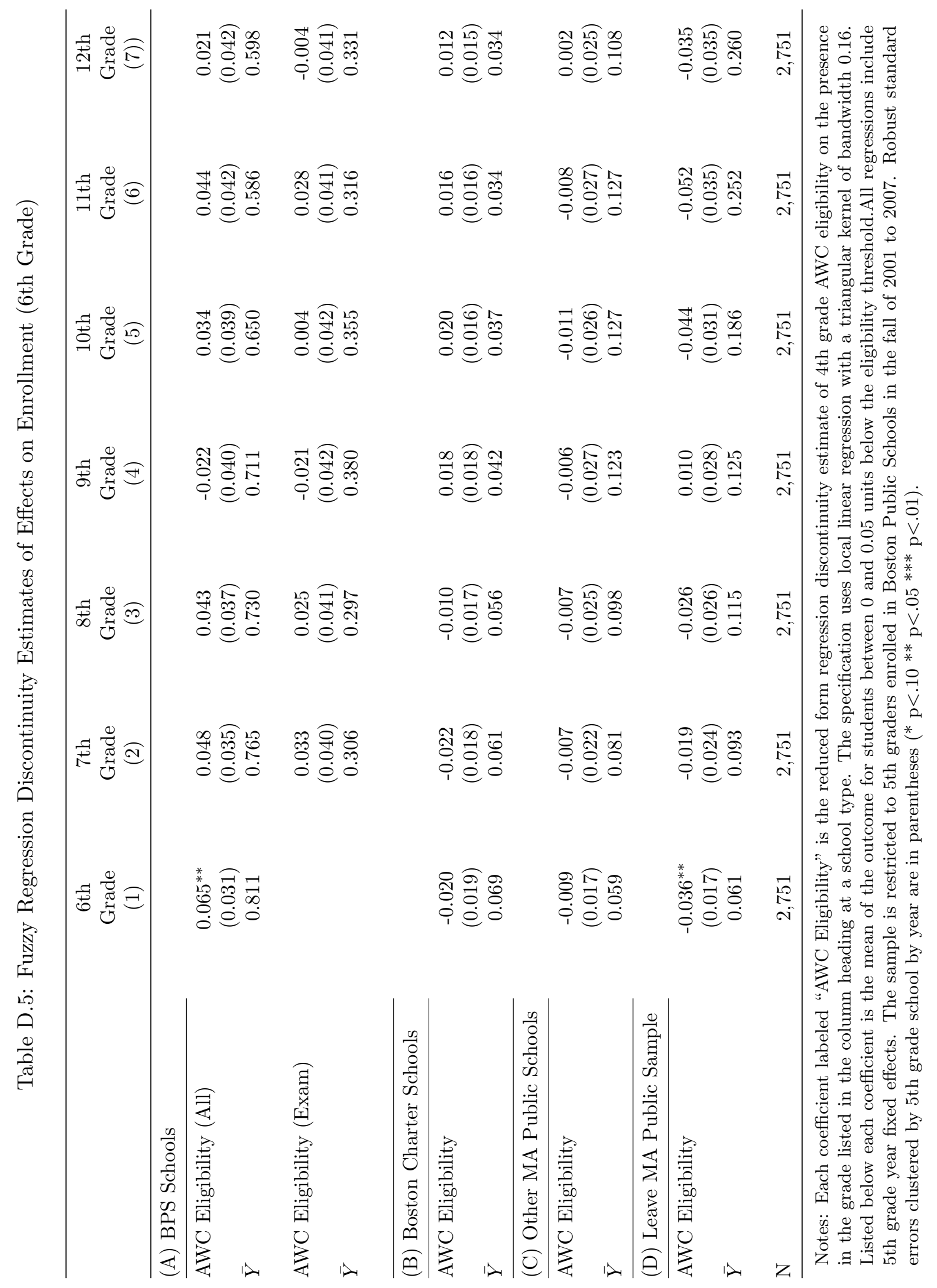




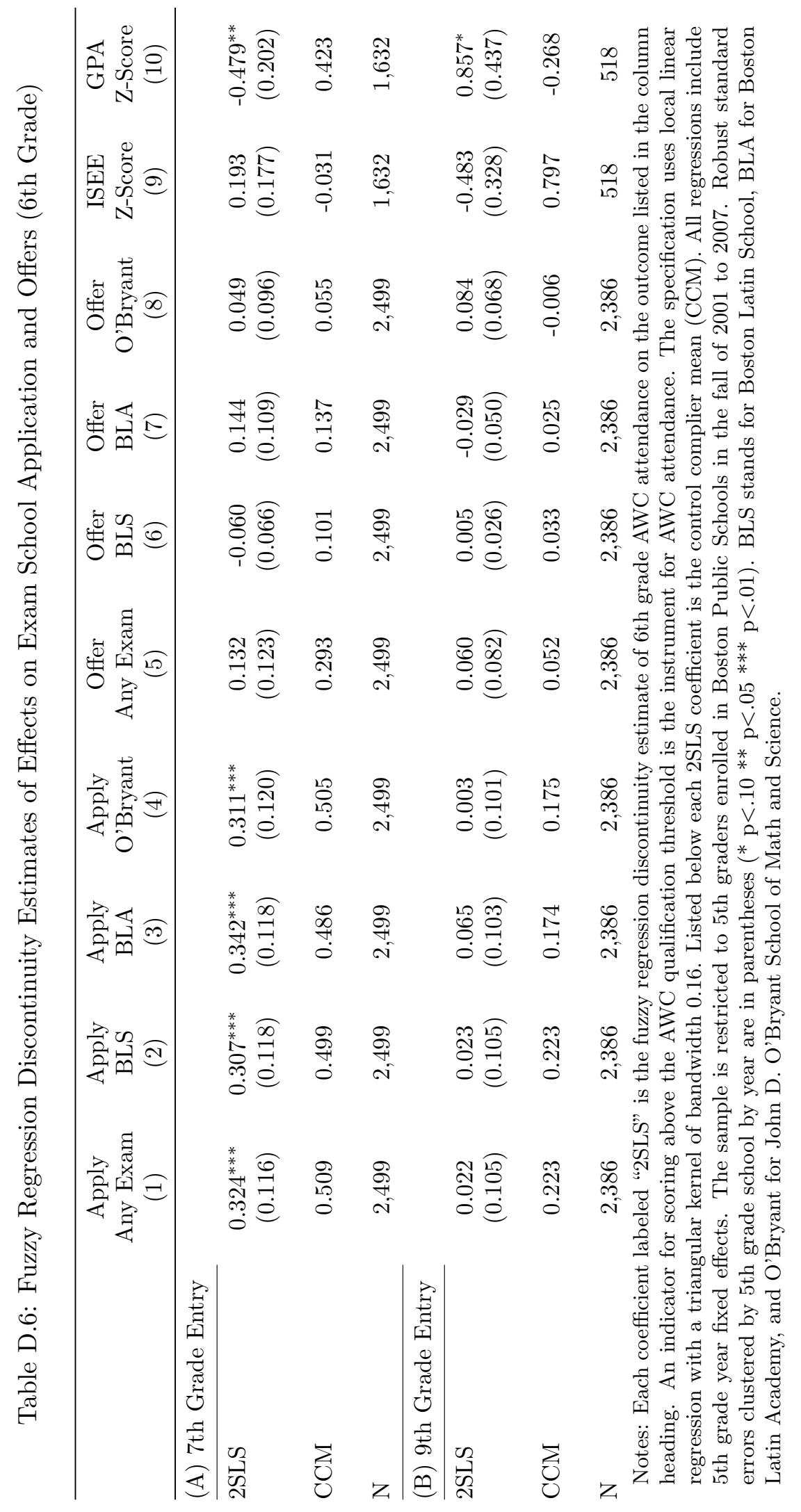


Table D.7: Fuzzy Regression Discontinuity Estimates of Effects on MCAS Indices (6th Grade)

\begin{tabular}{|c|c|c|}
\hline & $\begin{array}{c}\text { Middle } \\
\text { School } \\
\text { (1) }\end{array}$ & $\begin{array}{c}10 \text { th } \\
\text { Grade } \\
(2)\end{array}$ \\
\hline \multicolumn{3}{|c|}{ (A) All Students } \\
\hline 2SLS & $\begin{array}{c}0.053 \\
(0.116)\end{array}$ & $\begin{array}{c}0.272 \\
(0.173)\end{array}$ \\
\hline $\mathrm{CCM}$ & 0.303 & 0.154 \\
\hline $\mathrm{N}$ (students) & 2,597 & 2,269 \\
\hline \multicolumn{3}{|c|}{ (B) Black and Latino Students } \\
\hline 2SLS & $\begin{array}{l}-0.040 \\
(0.148)\end{array}$ & $\begin{array}{c}0.125 \\
(0.212)\end{array}$ \\
\hline $\mathrm{CCM}$ & 0.261 & 0.133 \\
\hline $\mathrm{N}$ (students) & 1,608 & 1,394 \\
\hline \multicolumn{3}{|c|}{ (C) White and Asian Students } \\
\hline$\overline{2 S L S}$ & $\begin{array}{c}0.237 \\
(0.196)\end{array}$ & $\begin{array}{c}0.610^{* *} \\
(0.299)\end{array}$ \\
\hline $\mathrm{CCM}$ & 0.398 & 0.181 \\
\hline N (students) & 989 & 875 \\
\hline
\end{tabular}

Notes: Each coefficient labeled "2SLS" is the fuzzy regression discontinuity estimate of 6th grade AWC attendance on the outcome listed in the column heading. An indicator for scoring above the AWC qualification threshold is the instrument for AWC attendance. The specification uses local linear regression with a triangular kernel of bandwidth 0.16. Listed below each coefficient is the control complier mean (CCM). All regressions include 5th grade year fixed effects. The sample is restricted to 5th graders enrolled in Boston Public Schools in the fall of 2001 to 2007. The MCAS index is the mean of all available MCAS subject test z-scores, standardized to be mean zero, standard deviation one. Elementary school regressions stack 4th and 5th grade outcomes, include grade fixed effects, and double cluster standard errors by 5 th grade school by year and student. Middle school regressions stack 6th, 7th, and 8th grade outcomes, include grade fixed effects, and double cluster standard errors by 5 th grade school by year and student $(* \mathrm{p}<.10 * * \mathrm{p}<.05 * * * \mathrm{p}<.01)$. 
Table D.8: Fuzzy Regression Discontinuity Estimates of Effects on Academic Outcomes (6th Grade)

\begin{tabular}{|c|c|c|c|c|c|c|}
\hline & $\begin{array}{c}\text { Took } \\
\text { Any AP } \\
(1)\end{array}$ & $\begin{array}{c}\text { \# APs } \\
\text { Taken } \\
(2)\end{array}$ & $\begin{array}{c}\text { Took } \\
\text { SAT } \\
(3)\end{array}$ & $\begin{array}{c}\text { SAT } \\
\text { Score } \\
(4)\end{array}$ & $\begin{array}{c}\text { On Time } \\
\text { HS Grad. } \\
\quad(5)\end{array}$ & $\begin{array}{c}\text { Late } \\
\text { HS Grade } \\
\quad(6)\end{array}$ \\
\hline \multicolumn{7}{|c|}{ (A) All Students } \\
\hline 2SLS & $\begin{array}{c}0.082 \\
(0.146)\end{array}$ & $\begin{array}{c}0.748 \\
(0.535)\end{array}$ & $\begin{array}{c}0.057 \\
(0.099)\end{array}$ & $\begin{array}{c}78.530 \\
(59.414)\end{array}$ & $\begin{array}{l}-0.141 \\
(0.104)\end{array}$ & $\begin{array}{c}0.018 \\
(0.150)\end{array}$ \\
\hline $\mathrm{CCM}$ & 0.511 & 1.362 & 0.815 & 1401.174 & 0.976 & 0.534 \\
\hline $\mathrm{N}$ & 2,078 & 2,078 & 2,078 & 1,767 & 2,078 & 2,078 \\
\hline \multicolumn{7}{|c|}{ (B) Black and Latino Students } \\
\hline 2SLS & $\begin{array}{l}-0.014 \\
(0.168)\end{array}$ & $\begin{array}{c}0.431 \\
(0.563)\end{array}$ & $\begin{array}{l}-0.073 \\
(0.122)\end{array}$ & $\begin{array}{c}36.132 \\
(65.299)\end{array}$ & $\begin{array}{l}-0.200 \\
(0.136)\end{array}$ & $\begin{array}{l}-0.110 \\
(0.172)\end{array}$ \\
\hline $\mathrm{CCM}$ & 0.525 & 1.299 & 0.867 & 1381.749 & 0.977 & 0.556 \\
\hline $\mathrm{N}$ & 1,264 & 1,264 & 1,264 & 1,037 & 1,264 & 1,264 \\
\hline \multicolumn{7}{|c|}{ (C) Asian and White Students } \\
\hline 2 SLS & $\begin{array}{c}0.351 \\
(0.263)\end{array}$ & $\begin{array}{c}1.931 \\
(1.197)\end{array}$ & $\begin{array}{l}0.379^{* *} \\
(0.176)\end{array}$ & $\begin{array}{l}203.799^{*} \\
(121.014)\end{array}$ & $\begin{array}{c}0.009 \\
(0.151)\end{array}$ & $\begin{array}{c}0.380 \\
(0.267)\end{array}$ \\
\hline $\mathrm{CCM}$ & 0.469 & 1.329 & 0.700 & 1434.921 & 0.977 & 0.469 \\
\hline $\mathrm{N}$ & 814 & 814 & 814 & 730 & 814 & 814 \\
\hline
\end{tabular}

Notes: Each coefficient labeled "2SLS" is the fuzzy regression discontinuity estimate of 6th grade AWC attendance on the outcome listed in the column heading. An indicator for scoring above the AWC qualification threshold is the instrument for AWC attendance. The specification uses local linear regression with a triangular kernel of bandwidth 0.16. Listed below each coefficient is the control complier mean (CCM). All regressions include 5th grade year fixed effects. The sample is restricted to 5th graders enrolled in Boston Public Schools in the fall of 2001 to 2007 . Robust standard errors clustered by 5 th grade school by year are in parentheses $(* \mathrm{p}<.10 * * \mathrm{p}<.05$ $* * * \mathrm{p}<.01)$. On time high school graduation looks for high school graduation 8 years after the 5 th grade exam for AWC eligibility. Late graduation is one year after that. 
Table D.9: Fuzzy Regression Discontinuity Estimates of Effects on College (6th Grade)

\begin{tabular}{|c|c|c|c|c|c|}
\hline & \multicolumn{3}{|c|}{ On Time College Enrollment } & \multirow{2}{*}{$\begin{array}{c}\text { College } \\
\text { Quality } \\
\$ 2014 \\
(4)\end{array}$} & \multirow{2}{*}{$\begin{array}{c}\text { Late } \\
\text { Enrollment } \\
\text { Any } \\
(5)\end{array}$} \\
\hline & $\begin{array}{l}\text { Any } \\
(1)\end{array}$ & $\begin{array}{c}\text { Four-year } \\
(2)\end{array}$ & $\begin{array}{c}\text { Two-year } \\
\text { (3) }\end{array}$ & & \\
\hline \multicolumn{6}{|c|}{ (A) All Students } \\
\hline 2SLS & $\begin{array}{l}-0.028 \\
(0.137)\end{array}$ & $\begin{array}{l}-0.001 \\
(0.145)\end{array}$ & $\begin{array}{l}-0.020 \\
(0.079)\end{array}$ & $\begin{array}{c}1302.106 \\
(5900.894)\end{array}$ & $\begin{array}{c}0.138 \\
(0.139)\end{array}$ \\
\hline $\mathrm{CCM}$ & 0.737 & 0.670 & 0.059 & 47543.338 & 0.701 \\
\hline $\mathrm{N}$ & 2,497 & 2,497 & 2,497 & 2,497 & 2,193 \\
\hline \multicolumn{6}{|c|}{ (B) Black and Latino Students } \\
\hline 2SLS & $\begin{array}{c}0.006 \\
(0.168)\end{array}$ & $\begin{array}{l}-0.046 \\
(0.177)\end{array}$ & $\begin{array}{c}0.061 \\
(0.099)\end{array}$ & $\begin{array}{c}983.299 \\
(6895.648)\end{array}$ & $\begin{array}{c}0.149 \\
(0.185)\end{array}$ \\
\hline $\mathrm{CCM}$ & 0.769 & 0.761 & -0.001 & 50642.633 & 0.742 \\
\hline $\mathrm{N}$ & 1,544 & 1,544 & 1,544 & 1,544 & 1,337 \\
\hline \multicolumn{6}{|c|}{ (C) Asian and White Students } \\
\hline 2SLS & $\begin{array}{l}-0.066 \\
(0.238)\end{array}$ & $\begin{array}{c}0.117 \\
(0.242)\end{array}$ & $\begin{array}{c}-0.178 \\
(0.129)\end{array}$ & $\begin{array}{c}3393.939 \\
(10701.673)\end{array}$ & $\begin{array}{c}0.140 \\
(0.246)\end{array}$ \\
\hline CCM & 0.666 & 0.493 & 0.167 & 41176.015 & 0.608 \\
\hline $\mathrm{N}$ & 953 & 953 & 953 & 953 & 856 \\
\hline
\end{tabular}

Notes: Each coefficient labeled "2SLS" is the fuzzy regression discontinuity estimate of 6th grade AWC attendance on the outcome listed in the column heading. An indicator for scoring above the AWC qualification threshold is the instrument for AWC attendance. The specification uses local linear regression with a triangular kernel of bandwidth 0.16. Listed below each coefficient is the control complier mean (CCM). All regressions include 5th grade year fixed effects. The sample is restricted to 5th graders enrolled in Boston Public Schools in the fall of 2001 to 2007 . Robust standard errors clustered by 5 th grade school by year are in parentheses $(* \mathrm{p}<.10 * *$ $\left.\mathrm{p}<.05^{* * *} \mathrm{p}<.01\right)$. On time college entrance looks at entry into college 10 years after the 5th grade exam for AWC eligibility. Late college entrance is calculated based on enrollment in college 9 years after the 5 th grade exam for AWC eligibility and includes on time enrollment. College quality earnings outcomes are measured by the estimated 2014 earnings of college attendees from the 1980-1982 birth cohorts from Chetty, et al. (2017). Students are assigned the earnings outcomes of the college they attend, by gender, even if they are not on time attendees. Students who do not attend college are assigned the outcomes for non-attendees of the same gender. 